Discussion Paper No. 10-068

\title{
The Demand for Climate Protection - An Empirical Assessment for Germany
}

Andreas Löschel, Bodo Sturm, and Carsten Vogt

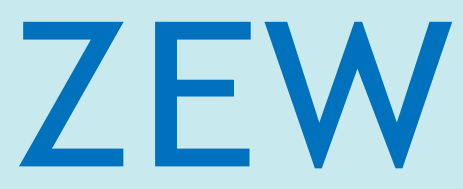

Zentrum für Europäische Wirtschaftsforschung $\mathrm{GmbH}$

Centre for European

Economic Research 
Discussion Paper No. 10-068

\title{
The Demand for Climate Protection - An Empirical Assessment for Germany
}

\author{
Andreas Löschel, Bodo Sturm, and Carsten Vogt
}

Download this ZEW Discussion Paper from our ftp server:

ftp://ftp.zew.de/pub/zew-docs/dp/dp10068.pdf

Die Discussion Papers dienen einer möglichst schnellen Verbreitung von neueren Forschungsarbeiten des ZEW. Die Beiträge liegen in alleiniger Verantwortung der Autoren und stellen nicht notwendigerweise die Meinung des ZEW dar.

Discussion Papers are intended to make results of ZEW research promptly available to other economists in order to encourage discussion and suggestions for revisions. The authors are solely responsible for the contents which do not necessarily represent the opinion of the ZEW. 


\section{Non-technical summary}

During the last two decades, the issue of international cooperation in climate protection has received increasing attention in economic research. The main focus has been on the underlying economic incentives for sovereign states to reach international environmental agreements. Besides the fundamental incentive problems of international cooperation, climate change policy has an important political economy dimension. National climate protection targets have to be politically acceptable to the domestic constituency. Moreover, even without international and national climate policies, individuals reduce $\mathrm{CO}_{2}$ emissions and voluntarily contribute to the global public good climate protection via carbon offsets. An empirical evaluation of the demand for carbon offsets and the people's willingness to pay (WTP) for climate protection is thus crucial for assessing the prospects of climate change mitigation.

Essentially, two methods for measuring the WTP for a particular good are available: First, one can infer the WTP from observing some economic transactions, i.e. the so-called revealed preferences approach. Second, one can ask people what they are willing to spend on some amount of a particular good or what quantity they are willing to purchase at a given price. This method is known as the stated preferences approach. Against the background of climate mitigation policies, all studies in the past that tried to measure WTP are varieties of the stated preferences approach. Thus, so far the WTP for climate protection has been derived from hypothetical decision situations only.

This study aims at eliciting the participants' real WTP for climate protection with the revealed preference approach. We conducted an experiment where people faced the opportunity to buy allowances from the European Emissions Trading Scheme (EU ETS). The sample consisted of 202 individuals from the residential population of Mannheim, Germany. Participants of the experiment received $€ 40$ and obtained information about (i) climate change and its effects on environment and human society and (ii) the EU ETS. Five prices were shown to each participant. The participants then indicated which quantity of permits they would like to buy for each price. After the experiment, one of the five prices was randomly selected and transactions were conducted accordingly. This method was chosen to guarantee incentivecompatibility and to implement a decision situation which is familiar to consumers since they have to state their demand at a given price. Purchased allowances were withdrawn from the EU ETS. From the observed price-quantity-combinations we derived participants' demand and the corresponding WTP. The experiment consisted of two treatments "Baseline" and "Reputation". In the latter, subjects knew in advance that they could obtain a certificate, verifying the purchased amounts.

The main result is that WTP for carbon reduction is very low: It amounts to approximately $€ 12$ per ton of $\mathrm{CO}_{2}$. Compared to the figures previously reported by stated preference studies on the WTP for climate protection this amount is fairly small. Moreover, the median WTP for our sample is zero. With respect to the treatment variable (certification of $\mathrm{CO}_{2}$ reduction), we find a positive reputation effect, i.e. the quantity climate protection demanded in the reputation treatment was significantly higher compared to the baseline treatment. The analysis of data on socio-economic variables as well as of attitudes towards global warming shows a negative age-effect and a positive effect of the formal educational level. An additional determinant of demand for climate protection is the preference for political parties: voters of the Green Party buy more permits. 


\section{Das Wichtigste in Kürze}

Obwohl der Klimaschutz seit Jahren mit hoher Priorität auf der politischen Agenda steht, ist die Höhe der realen Zahlungsbereitschaft für das globale Gut Klimaschutz weitestgehend unbekannt. Die reale Zahlungsbereitschaft für Klimaschutz stellt aber eine zentrale Größe dar, wenn es um die Bereitschaft eines Landes geht, sich zu bindenden Emissionsreduktionen zu verpflichten. Damit ein Land Vermeidungsaktivitäten unternimmt, die zumindest kurz- und mittelfristig signifikante Kosten verursachen, muss eine hinreichend hohe Zahlungsbereitschaft in der Bevölkerung existieren. Auch für freiwillige private Aktivitäten im Klimaschutz ist eine positive Zahlungsbereitschaft notwendig.

Wie hoch die Zahlungsbereitschaft für Klimaschutz ist, kann letztlich nur empirisch ermittelt werden. Grundsätzlich gibt es zwei Methoden zur Ermittlung der Zahlungsbereitschaft für ein Gut. Erstens, die Zahlungsbereitschaft kann aus einer realen ökonomischen Transaktion abgeleitet werden. Zweitens, man kann Menschen fragen, was sie unter bestimmten Bedingungen für das Gut zu zahlen bereit sind. Alle verfügbaren Studien zur Zahlungsbereitschaft für Klimaschutz nutzen solche Befragungen. Es wird somit die hypothetische Zahlungsbereitschaft für Klimaschutz erhoben.

In dieser experimentellen Studie wird erstmals die reale Nachfrage nach Klimaschutz ermittelt und damit zugleich die reale Zahlungsbereitschaft für Klimaschutz erhoben. Auf Grund der Existenz des Europäischen Emissionshandels für Kohlendioxid $\left(\mathrm{CO}_{2}\right)$ ist es möglich, direkt die reale Nachfrage für die Stilllegung von $\mathrm{CO}_{2}$-Zertifikaten unter kontrollierten Bedingungen zu erheben. An der hier vorgestellten Studie nahmen 202 Mannheimer Bürger im Alter von 18 bis 75 Jahren teil. Die Teilnehmer erhielten eine Aufwandsentschädigung in Höhe von $40 €$, wurden über den Klimawandel und die Wirkungsweise des Emissionshandels informiert und konnten schließlich - freiwillig und anonym - $\mathrm{CO}_{2}$-Zertifikate kaufen. Jeder Teilnehmer konnte für fünf verschiedene Preise die individuelle Nachfrage nach Zertifikaten angeben, wobei schließlich ein Preis als bindend ausgelost wurde. Der verwendete Mechanismus zur Ermittlung der Nachfrage ist anreizkompatibel, d.h., jeder Teilnehmer hatte einen Anreiz, seine tatsächliche individuelle Nachfrage anzugeben. Die an die Teilnehmer verkauften Zertifikate wurden erworben und stillgelegt. Damit wurde die Gesamtmenge aller zur Verfügung stehenden Zertifikate im Emissionshandel exakt um diese Menge reduziert, d.h., es wurde ein realer Beitrag zum Klimaschutz geleistet.

Insgesamt sind $62 \%$ der nachgefragten Mengen Null, so dass der Median der realen Zahlungsbereitschaft Null ist. Das arithmetische Mittel der realen Zahlungsbereitschaft beträgt hingegen ca. $12 €$ pro Tonne $\mathrm{CO}_{2}$. Ältere Teilnehmer kaufen deutlich weniger Zertifikate als jüngere. Dagegen kaufen Teilnehmer mit höherem Bildungsniveau und Wähler der Grünen deutlich mehr Zertifikate. Darüber hinaus haben Teilnehmer, deren Kaufentscheidung beurkundet wird, eine höhere Nachfrage nach Klimaschutz. 


\title{
The Demand for Climate Protection
}

\section{An Empirical Assessment for Germany}

\author{
Andreas Löschel ${ }^{\mathrm{a}}$, Bodo Sturm ${ }^{\mathrm{a}, \mathrm{b}}$, and Carsten Vogt ${ }^{\mathrm{c}}$ \\ ${ }^{\mathrm{a}}$ Centre for European Economic Research (ZEW), Mannheim \\ ${ }^{\mathrm{b}}$ Department of Business Administration, Leipzig University of Applied Sciences \\ ${ }^{c}$ Department of Business Administration, Bochum University of Applied Sciences
}

\author{
E-mail: \\ loeschel@zew.de, \\ bodo.sturm@wiwi.htwk-leipzig.de, \\ carsten.vogt@hs-bochum.de
}

October 2010

\begin{abstract}
In this paper, we investigate the real demand for climate protection. For this purpose we conducted a framed field experiment with a sample of the residential population in Mannheim, Germany. Participants were endowed with $€ 40$ and given the opportunity to contribute to climate protection by purchasing European Union Allowances. Purchased allowances were withdrawn from the European Emissions Trading Scheme (EU ETS). While the median willingness to pay (WTP) for climate protection is zero the mean WTP is approximately $€ 12 / \mathrm{tCO}_{2}$. We analyse determinants of the observed individual demand behaviour and discuss the potential consequences, which result from the remarkably low WTP and its distribution for German climate policy.
\end{abstract}

JEL classification: Q51, Q54, C93

Keywords: Experimental economics, demand for climate protection, climate change, willingness to pay

Acknowledgements: The authors thank Martin Achtnicht, Eva Benz, and Stefan Boeters for helpful comments. 


\section{Introduction}

During the last two decades, the issue of international cooperation in climate protection has received increasing attention in economic research. The main focus has been on the underlying economic incentives for sovereign states to reach international environmental agreements. Since climate protection is a problem of providing a global public good, it is faced with severe incentive problems for governments that try to maximise their net economic benefits. The game-theoretical literature has provided important insights into the difficulties of establishing effective and efficient cooperation on the provision of climate protection (see Finus 2001 for an overview).

Beyond the fundamental incentive problems of international cooperation, climate change policy has an important political economy dimension. National climate protection targets have to be politically acceptable to the domestic constituency. In the standard political economy approach, any government is motivated by the objective of maximizing its political income, i.e. the probability of being re-elected. In order to be re-elected, the government must consider the preferences of the pivotal voter, who can be approximated by the median voter in a democracy. Thus, the national median voter imposes a restriction on what would be acceptable to a government in international environmental negotiations. Ultimately, one would expect a government only to enter into agreements that are acceptable to the median voter. From a political economy point of view, thus, the median voter's willingness to pay (WTP) for environmental protection determines the outcome of international environmental negotiations. Surprisingly, this fact has been widely ignored (one notable exception is Congleton 1992). Moreover, even without international and national climate policies, individuals reduce $\mathrm{CO}_{2}$ emissions and contribute voluntarily to the global public good (see Hamilton et al. 2008 for an overview of voluntary carbon markets). These carbon offsets are analysed theoretically by Kotchen (2009) and Gans and Groves (2010). An empirical evaluation of the demand for carbon offsets and the people's WTP for climate protection is thus crucial for evaluating the prospects of climate change mitigation.

Essentially, two methods for measuring the WTP for a particular good are available: First, one can infer the WTP from observing some economic transaction, i.e. the so-called revealed preferences approach. Second, one could ask people what they would be willing to spend for some amount of the good, or what quantity they would be willing to purchase at a given price. This method is known as stated preferences approach. Against the background of climate 
mitigation policies, all studies in the past that tried to measure WTP are varieties of the stated preferences approach. Due to the hypothetical character of the decision situation given in this approach (Shogren 2005, Murphy et al. 2005), the reliance on stated preferences only is surprising. Meanwhile, however, the revealed preference approach can be used as a complementary method to observe preferences for climate protection: Since 2005, the European Emissions Trading Scheme (EU ETS) has been in place. This enables researchers to offer the purchase of emissions allowances from the EU-market and in turn directly observe the demand for climate protection or respectively the WTP. Our paper follows this approach. We conducted a framed field experiment (see Harrison and List 2004 for a classification of experiments) in which people were given the opportunity to buy European Union Allowances (EUAs) from the EU ETS. Participants of our experiment received $€ 40$. To induce the demand for climate protection the following method was applied: Five prices were shown to each participant. The participants then indicated which quantity of permits they would like to buy for each price. After the experiment, one of the five prices was randomly selected and transactions were conducted accordingly. This method was chosen to guarantee incentivecompatibility and to implement a decision situation which is familiar to consumers since they have to state their demand at a given price. Purchased allowances were withdrawn from the EU ETS. From the price-quantity-observations we derived participants' demand and the corresponding WTP. Our experiment consisted of two treatments "Baseline" and "Reputation". In the latter, subjects knew in advance that they could receive a certificate, verifying the purchased amounts.

In the experiment, participants were given a real-life opportunity to contribute to climate protection - a global public good characterised by non-rivalry and non-excludability - by purchasing EUAs. It is evident that in the experiment described, individuals only have marginal impact on global emissions. Similarly, a small single country will also be unable to significantly influence global emission. This approach differs from hypothetical scenarios usually chosen in stated preference studies, in which participants are required to state their WTP under the assumption that climate protection will be collectively provided at a specific level (see Johnson and Nemet 2010 for a survey). Thus, in our study we elicit the real WTP for climate protection from a purely individual perspective without any assumption on collective action to provide emissions reduction.

Our main result is that WTP for $\mathrm{CO}_{2}$ reduction is very low: It amounts to approximately $€ 12$ per ton of $\mathrm{CO}_{2}\left(\mathrm{tCO}_{2}\right)$. Compared to the figures previously reported by stated preference studies on the WTP for climate protection, this amount is relatively small. Moreover, the 
median WTP for our sample is zero. With respect to the treatment variable (certification of $\mathrm{CO}_{2}$ reduction), we find a positive reputation effect, i.e. the quantity of climate protection demanded in the reputation treatment was significantly higher compared to the baseline treatment. The analysis of data on socio-economic variables as well as attitudes towards global warming showed a highly significant negative age-effect and a highly significant positive effect on the formal educational level. An additional determinant of demand for climate protection is the preference for political parties: voters of the Green Party buy more permits.

The paper is structured as follows. In Section 2 we briefly survey the literature on WTP for the mitigation of global warming. Section 3 explains our setting for measuring the demand for climate protection and thus the WTP for the reduction of one $\mathrm{tCO}_{2}$. In Section 4 states the results. Section 5 contains a discussion of our findings and concludes.

\section{Literature overview: A broad range of numbers}

Several stated preferences studies have recently explored the question of WTP for the mitigation of climate change. In general, there are two kinds of studies: (i) studies that estimate WTP as a total amount of money or percentage of income people are willing to give up per unit of time, e.g. within a year, in order to achieve a specific amount of mitigation, and (ii) studies that measure WTP as the amount of money people would be willing to spend on the reduction of one $\mathrm{tCO}_{2}$. In a recent survey, Johnson and Nemet (2010) surveyed 27 studies and achieved the result that the WTP for climate protection ranged between $\$ 22-\$ 437$ per household annually, with a mean of $\$ 167$ and a median of $\$ 135$. One major problem of comparing different WTP is the fact that the values were surveyed under different scenarios. Thus, the environmental goods evaluated in the WTP estimates vary extensively. Since in our study participants were offered EUAs, we refer to the second branch of studies which obtains WTP values measured in monetary units per $\mathrm{tCO}_{2}$.

MacKerron et al. (2009) estimate the WTP for voluntary carbon offsets against an aviationrelated background. Participants of their study were asked what they would be willing to pay to offset their $\mathrm{CO}_{2}$ emissions during a hypothetical flight from New York to London. Using a dichotomous contingent valuation design, they estimated the mean WTP for the offset to be approximately $£ 24 / \mathrm{tCO}_{2}$. In the second part of their study they try to identify the value of several co-benefits that might be associated with the reduction of $\mathrm{CO}_{2}$ (like, e.g. human development or conservation of biodiversity). Their main findings are that co-benefits are 
positively valued and the total WTP for offsetting, including co-benefits, is higher compared to WTP for offsetting alone. In a similar study, Brouwer et al. (2007) asked passengers at the Amsterdam Schiphol airport for their WTP to reduce $\mathrm{CO}_{2}$ emissions caused by their flights. Brouwer et al. (2007) used a double bounded dichotomous CV design, enabling them to estimate WTP's upper and lower bounds. The mean WTP for the reduction of one $\mathrm{tCO}_{2}$ across all passengers amounts to $€ 25$, with a remarkable geographic variety: Mean WTP for Asians is the lowest amount with a value of $€ 10 / \mathrm{tCO}_{2}$ while it is highest for Europeans (mean value of $€ 41 / \mathrm{tCO}_{2}$ ). The average WTP is well in line with figures reported in MacKerron et al. (2009).

Achtnicht (2009) measures WTP for the reduction of $\mathrm{CO}_{2}$ using data from interviews with more than 600 potential car-buyers across Germany. The interviewees were presented a stated preference choice experiment consisting of hypothetical car types that differed in various characteristics like, e.g., price, propulsion technologies, fuel type and $\mathrm{CO}_{2}$ emissions per 100 kilometres. Relying on a utility maximisation approach and employing a mixed-logit model, the WTP for the reduction of one $\mathrm{tCO}_{2}$ can be indirectly inferred from the choices revealed in the survey. On average the estimated WTP amounts to $€ 476 / \mathrm{tCO}_{2}$, which is much higher than the above mentioned estimates.

Viscusi and Zeckhauser (2006) analysed the willingness to pay higher petrol taxes in order to avoid global warming among Harvard graduate students in law and public policy. They identified an average WTP of $\$ 0.79$ per gallon of petrol and the median WTP to be $\$ 0.44$. Since there is a constant relation between petrol input and $\mathrm{CO}_{2}$ emissions, these values can easily be converted into $\$ 89 / \mathrm{tCO}_{2}$ (mean) respectively $\$ 50 / \mathrm{tCO}_{2}$ (median). ${ }^{1}$ Given these values and assuming an annual average mileage of 10,000 miles, participants would in general be willing to spend approximately $\$ 1,500 /$ year (\$125/month). In addition, Viscusi and Zeckhauser ask for the WTP/income percentage ratio. They find that people are willing to spend $3 \%$ of their personal annual income. This translates into $\$ 4,500 / y e a r$, a much higher estimate than the value obtained from the petrol tax design. Viscusi and Zeckhauser attribute this difference to anchoring effects and prefer the estimate of willingness to pay derived from the specific petrol tax question instead of the results from the income vehicle.

\footnotetext{
1 One liter of petrol leads to 2,333 gram of $\mathrm{CO}_{2}$. Of course, this calculation assumes that the WTP is not affected by the frame of the hypothetical decision situation.
} 
This literature overview shows that WTP figures, in case of global warming, are highly diverse. WTP seems to be sensitive to a couple of factors, including the particular design of the study, e.g. which policy options participants face. Moreover, the number of topics included in a survey may influence participants' valuation (the so-called "embedding effect"). And last but not least, also distributional consequences affect WTP. Cai et al. (2008) analyse the impact of distributional preferences on WTP for mitigation of climate change. Their results provide strong evidence that WTP is heavily affected by the distributional impacts of the relevant policy framework. This contradicts the (neo-)classical assumption that efficiency and equity concerns can be separated. In a similar study, Lee and Cameron (2008) also demonstrate eco-system impacts and burden sharing of mitigation efforts to have dramatic impacts on WTP.

The existent estimates are exclusively based on the stated preferences approach. While there have been considerable efforts to improve its validity - cheap talk script (Cummings and Taylor 1999, Olar et al. 2007) and the use of certainty scales (Champ et al. 2005) are demand revealing techniques which try to minimise the hypothetical bias - decision making in the survey approach remains hypothetical. Therefore this study assesses the WTP for climate protection with a complementary method - a framed field experiment.

\section{The experiment}

The aim was to find out whether people would indeed be willing to spend the amounts stated for climate protection, if it was their own real money. To elicit the WTP for a reduction of atmospheric $\mathrm{CO}_{2}$ we used an experimental approach asking people to give up real money as an alternative to the survey approach. The EU ETS was employed as a vehicle and emission reductions were directly sold to the subjects. This section presents the procedures used in the experiment, first the mechanism to elicit the WTP for $\mathrm{CO}_{2}$ allowances followed by the descriptions of the concrete implementation.

\subsection{Mechanism design}

Experimental studies have applied a wide variety of incentive-compatible mechanisms to elicit the WTP for goods. In general, a mechanism is considered incentive-compatible if an individual's dominant strategy is to behave in such a way that valuations are truthfully revealed. For example, the following incentive-compatible procedures were used in recent literature: the Vickrey $2^{\text {nd }}$ price auction (e.g. Noussair et al. 2002, Hayes et al. 1995), the 
random $n$th price auction (e.g. List 2003, Huffman et al. 2007), and the Becker-DeGrootMarschak (BDM) mechanism (e.g. Noussair et al. 2004, Lusk and Fox 2003). In our study, we decided to use a modification of the BDM mechanism (Becker et al. 1964), in order to elicit the real demand for climate protection. Each participant was confronted with five different prices ordered from high to low. Prices were randomly selected from a uniform distribution of prices in $€ 0.20$ steps between $€ 0.20$ and $€ 5.00 .^{2}$ Each participant indicated the quantity she or he would be willing to buy at each of the five prices. Finally, one of the prices was randomly selected and the transaction was carried out at the corresponding price. Participants who did not wish to buy permits at a specific price indicated a quantity of zero.

Selecting the mechanism to elicit individuals' real demand, we had to account for the heterogeneity of the participants in the experiment. In particular, we had to ensure that the mechanism rules were comprehensible, also to people who were not familiar with the rather artificial decision situation in the experiment. For our experiment, the BDM mechanism seemed to be appropriate, since this mechanism is relatively simple and creates an individual demand function with five price-quantity-combinations. Moreover, the procedure of asking the participants for the quantity demanded at a given price we chose, corresponds to the participants' everyday live decision situation.

\subsection{Implementation}

For the recruitment of participants, around 2,200 letters of invitation were randomly distributed in Mannheim city centre, Germany. The information that people received at this stage was that there would be a survey in which they could buy products and that they would receive a remuneration of $€ 40$. Since several studies show that if people bid using windfall money they are likely to overstate their WTP (e.g. Cherry 2001, Cherry et al. 2002), it was already emphasised in the letter that the amount of $€ 40$ was a remuneration for taking part in the study. By doing so participants should feel being entitled to the money. A relatively high remuneration was used in order to avoid underrepresentation of people with high opportunity costs of time. The experiment took place in March 2010 on the premises of the Centre for

2 The price range (between $€ 2 / \mathrm{tCO}_{2}$ and $€ 50 / \mathrm{tCO}_{2}$ ) was chosen according to observed and expected EUA prices. The average closing spot price of EUAs on the environmental trading exchange BlueNext was $€ 12.87 / \mathrm{tCO}_{2}$ in March 2010. The impact assessment of the Climate change and renewable energy package estimated carbon prices in the range of $€ 30 / \mathrm{tCO}_{2}$ to $€ 39 / \mathrm{tCO}_{2}$ by 2020 (European Commission 2008). Most recent forecasts are between $€ 20 / \mathrm{tCO}_{2}$ and $€ 40 / \mathrm{COO}_{2}$ for Phase 3 of the EU ETS (Thomson Reuters 2010, Barclays Capital 2010, Löschel et al. 2010). 
European Economic Research (ZEW) in Mannheim, Germany. A total of 202 participants took part in the experiment. Each of the six sessions had 28 to 39 participants. ${ }^{3}$ At the beginning of each session, participants individually drew lots to determine their ID number (which was kept private). Afterwards, they received the remuneration of $€ 40$ and the instructions. ${ }^{4}$ Finally, participants could chose a table. Participants were not allowed to talk to each other. If they had questions, the experimenter answered them privately.

Experimental sessions lasted for about 60 to 75 minutes. At first, participants filled out an initial questionnaire enquiring about socio-economic characteristics and climate change. Then, the selling procedure was explained in the instructions. Participants additionally saw a first presentation of a concrete (but unrelated to $\mathrm{CO}_{2}$ permits) example of the BDM mechanism and had to fill out a short quiz that checked their understanding. After that, participants were given information about (i) climate change and its effects on the environment and human society, and (ii) the EU ETS. In the information about the EU ETS we put emphasis on the fact that buying and withdrawing permits actually reduces the EU emissions. Participants were reassured that all transactions would be carried out and that the final purchases and withdrawing of permits would be announced on the ZEW webpage. Finally, participants were informed that they had the opportunity to buy permits in $100 \mathrm{~kg}$ units with their own money and could therefore contribute to the overall reduction of $\mathrm{CO}_{2}$ emissions. In order to make individual $\mathrm{CO}_{2}$ emissions more tangible participants saw a second presentation with three specific examples of activities resulting in emissions of $100 \mathrm{~kg} \mathrm{CO}{ }_{2} .5$ Then each participant was given five different prices ordered from high to low. Each participant had to announce the quantity she or he would like to purchase. By doing so, the maximal expenditures were limited to $€ 40$. The fact that all decisions were voluntary was stressed before this decision. Finally, participants filled out a second questionnaire answering questions about possible motives to contribute (or not to contribute) to climate protection. Afterwards, participants left the room one-by-one. Participants who had announced positive quantities had to draw lots to determine the price at which the transaction would take place. Each subject paid the corresponding amount of money and received the information where the

\footnotetext{
3 The actual response rate, however, was higher than $9 \%$ because during the registration we screened all applications according to gender and age, i.e. people from certain age groups that were already overrepresented in the sample were not allowed to take part.

${ }^{4}$ See Annex II for the translated instructions.

5 We choose the following examples: (i) a $720 \mathrm{~km}$ drive with a VW Golf $1.4 \mathrm{TSI}$ leads to $100 \mathrm{~kg} \mathrm{CO}_{2}$, (ii) the electricity consumption of a two-person household in 19 days also leads to $100 \mathrm{~kg} \mathrm{CO}_{2}$, and (iii) $100 \mathrm{~kg} \mathrm{CO}$ are $0.9 \%$ of the annual average per capita $\mathrm{CO}_{2}$ emissions in Germany.
} 
results of the study would be published at the ZEW webpage. After that, participants left the institute. All other participants had already left the institute directly after the second questionnaire.

The total quantity of permits, 52.5 tons, was bought and directed to the DEHSt account 17034-34. The only purpose of the account is to delete permits at the end of the year. The whole process was made public.

Our experiment contained one treatment variable. In order to analyse possible effects of reputation when contributing to the global public good a subset of participants $(\mathrm{N}=67$ of 202) could receive a certificate. The certificate listed the name of the participant and the quantity bought. Furthermore, the procedure and the aim of the study were briefly described. Subjects were informed about the certificate in advance during the second presentation.

\section{Results}

In this section we present the results of the experiment. First, we briefly describe the pool of selected participants followed by the results of the first questionnaire on attitudes with regard to climate change. Second, we analyse the purchase decision and compute the average WTP for climate protection. The third part analyses the results of the second questionnaire on buying motives. Finally, the findings of regression models are presented in order to analyse the determinants of subjects' demand for climate protection.

\subsection{Pool of participants and their attitudes towards climate change}

Before announcing their purchase decisions, participants answered a first questionnaire. The main purpose of this questionnaire was to collect data about socio-economic characteristics and the attitudes and experiences with respect to climate change. Tables 3 and 4 (see Annex I) present the participants' socio-economic characteristics. Our subject pool covered all required age groups for men as well as for women. With respect to the variables 'age' and 'sex' our pool represented the residential population of Mannheim (StaLa BWL 2007). The hypothesis of equal relative frequencies for male and female age groups between the selected participants and the resident population cannot be rejected. ${ }^{6}$ Quite surprisingly, the fraction of voters with

\footnotetext{
6 Chi-squared $=4.94, \mathrm{df}=3, p=0.176$ for male subjects and chi-squared $=4.75, \mathrm{df}=3, p=0.192$ for female subjects. There are four age groups: 18-24, 25-39, 40-64, and 65-75.
} 
"green preferences" among our subjects was relatively high, since $23 \%$ would vote for the Green Party. This figure is nearly twice as high as the proportion of votes that this party achieved in the last election of the state parliament in Baden-Wuerttemberg (in 2006: $11.7 \%) .^{7}$

Tables 5, 6 and 7 (Annex I) present participants' attitudes and experiences with regard to climate change. With respect to the level of information about climate change, half of the participants were "averagely informed" (51\% of all subjects), and about one third was rather "well informed". Besides, $52 \%$ of the participants stated that media influence on their own perception of climate change was very strong or rather strong. Climate change matters: $52 \%$ were "rather concerned" about climate change and about $12 \%$ were "very concerned". However, there were also participants who remained neutral (17\%) with respect to this issue or "rather not concerned" (13\%) or "not at all concerned" (4\%). Participants' attitude differed with respect to the expectation of negative consequences caused by climate change for their own personal life: $48 \%$ expected negative consequences, $52 \%$ did not. Positive consequences caused by climate change were only expected by $8 \%, 90 \%$ did not expect positive effects.

Among the participants there seemed to be awareness that intergenerational equity may be affected by climate change. While about $24 \%$ stated that climate change posed a "rather serious or very serious threat" to them or their families, about $38 \%$ stated that climate change posed such a threat to their children and about $84 \%$ to future generations in general. Also intra-generational equity was an issue. About $34 \%$ stated that climate change posed a "rather serious or very serious threat" to people in Germany, about $52 \%$ stated that climate change posed such a threat to people in other industrialised countries and about $86 \%$ indicated that climate change was a threat to people in developing countries.

Being asked whether they had been personally affected by negative effects of climate change about $9 \%$ indicated "yes", only about $4 \%$ confirmed that they had been affected positively by climate change. The relative majority of participants $(41 \%)$ thought that the impacts of climate change are already visible. About $39 \%$ expected that the impacts will become visible within the next 50 years. The overwhelming majority $(87 \%)$ supported the statement that

\footnotetext{
${ }^{7}$ See http://www.landtagswahl-bw.de. Recent polls, however, indicate a higher fraction of votes (27\%) for the Green Party. See http://www.presseportal.de/pm/7169/1678447/swr_suedwestrundfunk (accessed on September 8th 2010).
} 
"there is still a need for commitment to fight climate change". Only about $6 \%$ disagreed with this statement.

We also asked participants who should be responsible for measures against climate change. On the one hand, participants were convinced that their "personal behaviour has an influence on climate change". About $70 \%$ rather agreed or even fully agreed with this statement. Even more, about $74 \%$ rather agreed or fully agreed with the statement that their behaviour to avoid climate change "can encourage others ... to behave the same way". On the other hand, $83 \%$ did not agree or rather did not agree with the statement that "the government is solely responsible for measures against climate change". We also asked subjects how they would evaluate two popular $\mathrm{CO}_{2}$ abatement measures. About $66 \%$ rather agreed or even fully agreed with the statement that "German citizen [s] should use as little electricity as possible" in order to mitigate climate change. In the same way about $78 \%$ supported the statement that "German citizen[s] should use their car ... as little as possible" in order to mitigate climate change.

\subsection{Quantity demanded and willingness to pay for climate protection}

In this section, we analyse participants' bidding behaviour. As mentioned before, five prices ranging from $€ 0.20$ to $€ 5.00$ in $€ 0.20$ steps were randomly selected and all decisions could have led to real purchases. Therefore, the number of observations is 1010. Table 1 summarizes the bidding behaviour. At all prices the median quantity (in $100 \mathrm{~kg} \mathrm{CO}$ ) purchased is zero. The arithmetic mean of the quantity purchased is 2.83 , i.e. $283 \mathrm{~kg} \mathrm{CO}$, indicating the existence of outliers on the right tail of the quantity distribution. With decreasing prices on average more permits are purchased. For the highest prices (price $p$ in $€ C$ ent), i.e. the price interval $420 \leq p \leq 500$, the mean quantity amounts to 0.59 only. For the lowest prices, i.e. the price interval $20 \leq p \leq 100$, the mean quantity purchased amounts to 8.41 , i.e. $841 \mathrm{~kg} \mathrm{CO}$. 
Table 1: Summary of bidding behaviour

\begin{tabular}{ccccccr}
\hline & \multicolumn{5}{c}{ Units (in 100 kg CO CO } \\
\hline Price range (in €Cent) $\downarrow$ & Min. & 1st Qu. & Median & Mean & 3rd Qu. & Max. \\
\cline { 2 - 7 } $420 \leq p \leq 500$ & 0.00 & 0.00 & 0.00 & 0.59 & 0.50 & 9.00 \\
$320 \leq p \leq 400$ & 0.00 & 0.00 & 0.00 & 0.76 & 1.00 & 11.00 \\
$220 \leq p \leq 300$ & 0.00 & 0.00 & 0.00 & 1.12 & 1.00 & 14.00 \\
$120 \leq p \leq 200$ & 0.00 & 0.00 & 0.00 & 3.33 & 5.00 & 28.00 \\
$20 \leq p \leq 100$ & 0.00 & 0.00 & 1.00 & 8.41 & 10.00 & 100.00 \\
All prices (in €Cent) $\downarrow$ & & & & & & \\
$20 \leq p \leq 500$ & 0.00 & 0.00 & 0.00 & 2.83 & 2.00 & 100.00 \\
\hline
\end{tabular}

The figures in Table 1 suggest a downward-sloping demand curve for climate protection, which will be discussed in more detail in Section 4.4. Figure 1 depicts the cumulated density function for quantities (in units of $100 \mathrm{~kg} \mathrm{CO}_{2}$, on the left side) and for expenditures (in $€ C$ ent, on the right side). ${ }^{8}$ Furthermore, the values for minimum, $1^{\text {st }}$ quartile, median, mean, standard deviation (SD), $3^{\text {rd }}$ quartile and maximum are indicated. Both distributions are characterised by a high frequency of observations on the left tail. With respect to quantities, a total of $75 \%$ were below or equal to 2 units, i.e. $200 \mathrm{~kg} \mathrm{CO}_{2}$. The maximum quantity demanded is 100 units. A slightly less extreme ratio holds for the expenditure: $75 \%$ are below or equal to $€ C$ ent 400 , the maximum is $€ C e n t 4,000$, i.e. a few individuals were willing to spend all their remuneration on climate protection. Furthermore, $62 \%$ of all quantities (and therefore also of all expenditures) are zero, i.e. across the entire price range a majority of individuals did not purchased emission reductions at all. Thus, the median values for quantities and expenditures are zero, but the mean values are positive (the mean quantity is 2.83 units of $100 \mathrm{~kg}$, the mean expenditure is $336.59 € C e n t)$.

\footnotetext{
${ }^{8}$ Revenues are equivalent to subjects' expenditures.
} 
Figure 1: Cumulated density function for quantities (left) and expenditures (right)
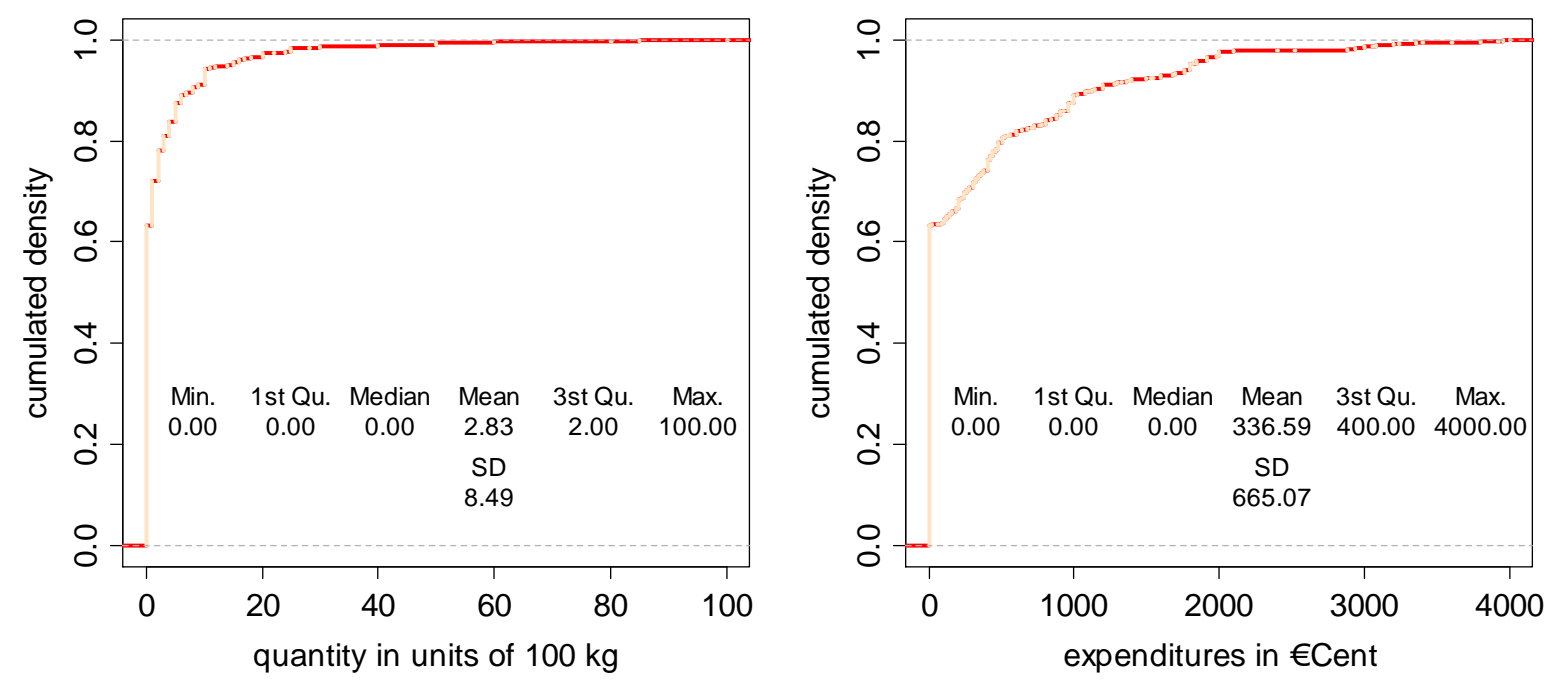

From the data above we can compute the mean WTP for climate protection by dividing the mean expenditure (€Cent 336.59) by the mean quantity demanded (2.83 units of $100 \mathrm{~kg} \mathrm{CO}$ ). This leads to the mean WTP of $€$ Cent 118.91 for one unit of $100 \mathrm{~kg} \mathrm{CO}_{2}$, i.e. $€ 11.89 / \mathrm{tCO}_{2}$. The median WTP is zero.

\section{Figure 2: Lorenz curve for quantities and expenditures}

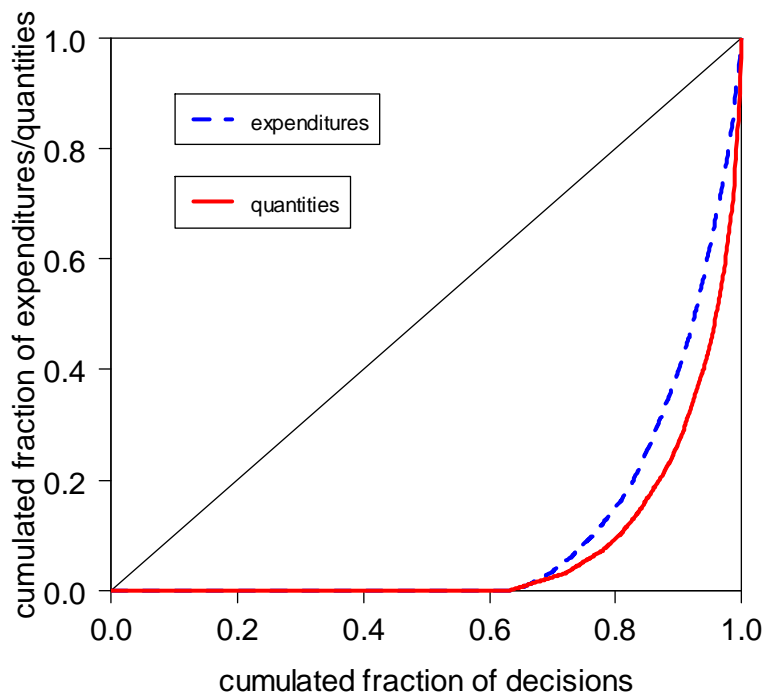

The Lorenz curve in Figure 2 confirms the impression that quantities as well as expenditures are highly concentrated. The highest $20 \%$ of all quantities (expenditures) contribute to approximately $91 \%(85 \%)$ of the sum of all quantities (expenditures). Thus, the data show a very dichotomous distribution of two types: a majority of participants with a zero WTP and few individuals who contribute significantly to climate protection. 
Directly after the purchase decision participants were asked to guess the current market price for one unit $\mathrm{CO}_{2}\left(=100 \mathrm{~kg} \mathrm{CO}\right.$ ). On average, participants overestimated the $\mathrm{CO}_{2}$ price (see Table 8 in Annex I). In March 2010, the average closing spot price of the European Union Allowances on the environmental trading exchange BlueNext was $€ 12.87 / \mathrm{tCO}_{2}$. One third believed that the price for one unit ranges between $€ 2$ and $€ 10$ per $100 \mathrm{~kg} \mathrm{CO}_{2}$. Only $12 \%$ had correct expectations with respect to the market price, i.e. they estimated the $\mathrm{CO}_{2}$ prices to be between $€ 1$ and $€ 2$ per $100 \mathrm{~kg} \mathrm{CO}_{2}$. However, almost all individuals were rather unsure about their price estimation, two thirds of subjects guessed when they were asked for their price estimates.

\subsection{Participants' motives to buy or to refuse to buy}

Directly after the purchasing decision participants were requested to answer questions about their buying motives. The questions were structured according to potential arguments to contribute to the global public good climate protection (see Tables 9 and 10 in Annex I). Being asked why they would like to contribute, the absolute majority stated that their contribution did not depend on other people's choices or decisions: $84 \%$ agreed to the statement "I want to contribute to climate protection - regardless what others do". 9 Reciprocity as a motive for contributions was less important. Only $55 \%$ stated that they would like to contribute because of the expectation that others would follow this example. Intra-generational equity was another important motive in the public debate on climate change. In our sample, the participants confirmed this assumption: $74 \%$ of the participants contributed "because especially people in poor countries will suffer from the consequences of climate change and [I] they want to do something against it". However, the argument that industrialised countries, among them Germany, caused climate change and thus people would be obliged to contribute more to climate protection received less affirmation (64\%). Besides intra-generational equity also intergenerational equity was an issue: $82 \%$ bought permits because future generations will suffer from climate change and the participants wanted to do something against it. The protection of flora and fauna as a buying motive was important for $76 \%$ of the participants.

9 If not otherwise mentioned, we aggregate the observations for "rather applicable" and "absolutely applicable" (Tables 9, 10 and 11 in Annex I) in this section. 
Other motives to purchase climate protection were, however, less important: "the government is not doing enough against climate change" (49\% approval), "it is my moral obligation" (49\%) and "because it is important to protect the creation" (44\%). According to the answers, social pressure was not a motive for buying. Being asked whether they bought "because [my] their environment (family, friends, colleagues) expect [me] them to", only $11 \%$ agreed. For $45 \%$ this motive was irrelevant. Due to the fact that there was direct contact to the ZEW staff during the experiment, participants might have been felt pushed to buy. However, considering the received answers this was rather not the motive. Being asked whether they "buy permits, because the organizers of this event expect [me] them to" $64 \%$ of subjects stated that this statement did absolutely not hold for them.

In our experiment, 83 of 202 participants, i.e. $41 \%$, did not buy at any price. We enquired about possible motives not to buy and looked at the approval rates afterwards (Table 11 in Annex I). ${ }^{10}$ The majority of (52\%) who did not buy any permit stated that "they [I] do not think their [my] buying of permits will actually reduce emissions in Europe”. This motive is well-known from the standard economic model of the homo oeconomicus. As the effect of the individual contribution to climate protection is costly but has negligible effects on climate protection, it is a dominant strategy not to contribute. Furthermore, $41 \%$ of those participants who refused to buy believe that "the market for permits does not work. We need prohibitions and commands". That means that a relative majority seemed to mistrust emission trading as such. They are less concerned about technical problems with measurement and control of $\mathrm{CO}_{2}$ emissions. Only $18 \%$ stated that they did not buy permits because "emissions ... [can't] actually be measured and controlled". Another motive for not buying was that participants already behaved in a climate conscious way. For $42 \%$ this was a relevant motive not to buy permits. Also distributional concerns seem to be a reason for subjects not to buy permits although the interpretation of answers is ambiguous here. On the one hand $36 \%$ refused to buy "because emissions trading anyhow suits the interests of the large scale industry only". On the other hand only $22 \%$ refused to buy permits because companies had received them for free and the latter would thus be subsidised. Remarkably, only for $20 \%$ the argument "emissions trading is principally unethical" was a motive not to buy. Again, responses show that participants trusted the ZEW. Only $7 \%$ did not buy permits because they did not trust

10 We implemented these questions after the first session. Subjects of the first session who didn't buy were counted as "no answer". 
ZEW. On the contrary this motive not to buy was absolutely not applicable for $35 \%$ of participants.

\subsection{Regression models}

In order to analyse determinants of individual demand behaviour, we provide regression estimates of the general form $\log Q=f(\log P, Z) \cdot \log Q$ is the natural $\log$ of the demanded quantity $+1, \log P$ is the natural $\log$ of the price and $Z$ is a vector of other independent variables. Since the dependent variable is censored from below, we use tobit regressions. Table 2 lists three different models to explain $\log Q$. The first model is simply an estimate for the demand function $\log Q=f(\log P)$. The estimated coefficient $(-0.363)$ is negative and above -1 , thus indicating a negatively sloped and inelastic demand function. The second model incorporates the price, different socio-economic characteristics and reputation as explanatory variables. The third model incorporates participants' attitudes towards climate change. Dummy variables are indicated with a "D".

The significant regression results (at least $p<0.1$ ) for the socio-economic variables can be summarised as follows. Males have a higher demand for climate protection than females. Older persons buy fewer permits than younger people. The individual income positively influences the willingness to contribute to climate protection. Participants with a university degree buy more permits. Voters of the Green Party also contribute more to climate protection. Furthermore, participants in the reputation treatment buy more permits than subjects in the no reputation treatment. In line with socio-economic variables several attitudes towards climate change influence the willingness to contribute to climate protection. Participants who stated that media influence on their own perception of climate change was rather strong bought more permits. The same holds for participants who are at least "rather strong" concerned about impacts of climate change. Finally, participants who believe that personal activity for climate protection is rather important have a stronger demand for climate protection. 
Table 2: Tobit regressions

\begin{tabular}{|c|c|c|c|}
\hline & $(1)$ & $(2)$ & (3) \\
\hline independent variables $\downarrow$ & $\log Q$ & $\log Q$ & $\log Q$ \\
\hline $\log P$ & $\begin{array}{l}-0.363^{* * *} \\
(10.91)\end{array}$ & $\begin{array}{l}-0.373 * * * \\
(11.88)\end{array}$ & $\begin{array}{l}-0.363^{* * * *} \\
(12.29)\end{array}$ \\
\hline male_D & & $\begin{array}{l}0.120 * * \\
(2.23)\end{array}$ & $\begin{array}{l}0.159 * * * \\
(2.93)\end{array}$ \\
\hline age & & $\begin{array}{l}-0.014 * * * \\
(7.36)\end{array}$ & $\begin{array}{l}-0.013 * * * \\
(7.32)\end{array}$ \\
\hline income & & $\begin{array}{l}0.051 * * * \\
(2.97)\end{array}$ & $\begin{array}{l}0.037 * * \\
(2.26)\end{array}$ \\
\hline religion_D & & $\begin{array}{l}-0.001 \\
(0.02)\end{array}$ & $\begin{array}{l}-0.019 \\
(0.36)\end{array}$ \\
\hline child_D & & $\begin{array}{l}0.059 \\
(0.86)\end{array}$ & $\begin{array}{l}0.065 \\
(0.97)\end{array}$ \\
\hline$e d u \_u n i \_D$ & & $\begin{array}{l}0.165^{* * * *} \\
(2.88)\end{array}$ & $\begin{array}{l}0.195 * * * \\
(3.50)\end{array}$ \\
\hline party_green_D & & $\begin{array}{l}0.269 * * * \\
(4.03)\end{array}$ & $\begin{array}{l}0.181 * * * \\
(2.92)\end{array}$ \\
\hline reputation_D & & $\begin{array}{l}0.163 * * * \\
(2.70)\end{array}$ & $\begin{array}{l}0.113^{*} \\
(1.95)\end{array}$ \\
\hline info_cc_D & & & $\begin{array}{l}-0.062 \\
(1.17)\end{array}$ \\
\hline media_infl_D & & & $\begin{array}{l}0.123 * * \\
(2.37)\end{array}$ \\
\hline concerns_cc_D & & & $\begin{array}{l}0.103^{*} \\
(1.78)\end{array}$ \\
\hline pers_activ_D & & & $\begin{array}{l}0.352 * * * \\
(6.05)\end{array}$ \\
\hline enc_other_D & & & $\begin{array}{l}0.046 \\
(0.70)\end{array}$ \\
\hline gov_resp_D & & & $\begin{array}{l}-0.108 \\
(1.24)\end{array}$ \\
\hline Constant & $\begin{array}{l}1.720 * * * \\
(9.99)\end{array}$ & $\begin{array}{l}1.994 * * * \\
(10.29)\end{array}$ & $\begin{array}{l}1.552 * * * \\
(8.15)\end{array}$ \\
\hline Observations & 1010 & 960 & 960 \\
\hline Pseudo R-squared & 0.05 & 0.10 & 0.13 \\
\hline
\end{tabular}

\section{Notes:}

(i) $*, * *, * * *$ significance at $10 \%, 5 \%, 1 \%$. Coefficients indicate marginal effects on unconditional expected value. Absolute value of $\mathrm{z}$ statistics are in parentheses.

(ii) Definition of variables: $\log Q$ : natural $\log$ of quantity in units of $100 \mathrm{~kg}$ demanded $+1 ; \log P:$ natural $\log$ of price in €Cent; male_D: 1 (0) if male (female), age: age in years; income: 1 if household income $<1 \mathrm{k€}, 2$ if $1 \mathrm{k€} \leq$ income $<2 \mathrm{k€}, 3$ if $2 \mathrm{k€} \leq$ income $<3 \mathrm{k€}, 4$ if $3 \mathrm{k€} \leq$ income $<4 \mathrm{k€,} 5$ if $4 \mathrm{k€} \leq$ income $<5 \mathrm{k€,} 6$ if income $\geq 5 \mathrm{k} €$; religion_D: 1 (0) if religious (not religious); child_D: 1 (0) if at least one child (no children); $e d u \_u n i \_D: 1(0)$ if university education (other); party_green_D: $1(0)$ if green voter (other); reputation_D: 1 (0) if treatment reputation (other); info_cc_good_D: 1 (0) if information about climate change is at least good (other); media_infl_D: 1 (0) if media influence on the perception of climate change is at least rather strong (other); concerns_cc_D: 1 (0) if concerns about climate change are rather strong (other); pers_activ_D: $1(0)$ if personal activity for climate protection is rather important (other); enc_other_D: 1 (0) if encouraging others for climate protection is rather important (other); gov_resp_D: 1 (0) if governmental responsibility for climate protection is rather important (other).

In general, the statistically significant effects of independent variables on the quantity demanded are only small in their magnitudes. There are, however, some interesting differences in the quantitative effects. According to the estimated coefficient in model (3), which shows the marginal effect of the independent variable ("var") on the unconditional expected value of the dependent variable (“ $\log Q$ ”), men, on average purchase 0.17 units more 
than women. ${ }^{11}$ If we compare a 20 -year-old participant with a 70-year-old, the older participant buys on average 0.92 units less. The effect of income can be computed in a similar way. If we take a participant with an income between $€ 5,000$ and $€ 6,000$ she or he on average purchases 0.20 units more compared to participants with an income below $€ 1,000$. The remaining variables with statistically significant effects are dummy variables and their quantitative effect on the demand can be computed accordingly. The strongest effect is generated by participants who believe that personal activity for climate protection is rather important. Those participants on average demand 0.42 units more. The effect of reputation, significant at the $10 \%$-level, has only a small effect. Participants in the reputation treatment on average buy 0.20 units more.

\section{Discussion and conclusion}

Several studies on the WTP for climate protection were written in the last decade. The existing studies are characterised by various definitions of the good to be valued. Moreover, the studies exclusively rely on surveys and use hypothetical scenarios to elicit stated preferences. The payment mechanisms employed range from household costs in general to specific increases for energy or fuel. The studies analyse a broad range of explanatory variables such as climate awareness, environmental values, risk perception, uncertainty and perceived fairness. Estimates of annual WTP to pay for households and WTP per $\mathrm{tCO}_{2}$ reduction vary enormously due to the differences described above, but also because of attitudes, socio-economic characteristics and geography.

We have complemented existing studies on the WTP in several aspects: First, we confront subjects with a real decision situation in which they can contribute to climate protection. Thereby, we elicit the real WTP for climate protection from a purely individual perspective without any assumption on collective action to provide emissions reduction. Second, we make use of an established mechanism for climate protection, the EU ETS. Allowances purchased by our participants were bought and withdrawn from the EU ETS. We found that WTP is higher with increasing levels of income, education, with greener political views and concerns about severe impacts of climate change. WTP for climate protection decreases with age and is lower for females than for males. There is also a positive reputation effect. Our analysis also showed a very dichotomous distribution of two types: a majority of subjects with a very low

\footnotetext{
${ }^{11}$ Computed as follows: $\Delta \log Q / \Delta \operatorname{var}=0.159 \Leftrightarrow Q=1.17 \Leftrightarrow$ quantity demanded $=Q-1=0.17$ units.
} 
WTP and few individuals who would spend almost everything on climate protection. Without doubt, our most important results are the overall low average WTP per $\mathrm{tCO}_{2}$ and the zero median WTP for climate protection. If people are asked to give up real money, WTP per $\mathrm{tCO}_{2}$ for climate protection is obviously much lower than in existing hypothetical studies.

This is indeed an "inconvenient truth" from a political economy perspective: There seems to be no political majority for substantial, i.e. costly climate policy. A majority of voters is not willing to bear significant costs in order to mitigate climate change. These results are quite remarkable given the fact that our study was conducted in Germany, a high income country, where concerns about climate change have existed for a long time. One might infer that WTP for climate protection in countries with lower income, less information and less concern among the public will be even lower (Carlsson et al. 2010 show this in a multiple country study for China, Sweden and the US). Thus, it seems plausible to assume that our low estimate of WTP is indeed an upper bound for WTP in other countries. On the other hand, an overwhelming majority of participants is concerned about the impacts of climate change and wants policy makers to do something against global warming because future generations or poor countries will suffer. Moreover, most participants seem to be willing to contribute unconditionally to climate mitigation, i.e. even without cooperative givings by others. This display of good will, however, does not result in a corresponding higher WTP, but it might help to explain the existing deficiencies in international climate agreements. The presumably overall low WTP for climate protection might to some extent explain why the Kyoto Protocol - so far the only existing international climate agreement - reduced to a mere symbolic policy (see e.g. Böhringer and Vogt 2004, Endres et al. 2000).

However, the median voter model can only partly explain what happens in real-life. While most countries, which ratified the Kyoto Protocol, are far away from reaching their reduction targets - which is by and large in line with the symbolic policy conjecture derived from low WTP - very few countries ${ }^{12}$ like Germany enacted costly climate policies in the past and substantially reduced their $\mathrm{CO}_{2}$ emissions. This observation is not in line with the conclusions from the median voter model in combination with our empirical low estimate of WTP. Other factors like the impact of green pressure groups might explain why German climate policy

\footnotetext{
12 To be precise, besides Germany it is only Great Britain which is on track with its Kyoto obligation.
} 
tended to deviate from the median voter outcome in the past. ${ }^{13}$ However, a thorough analysis and discussion of these issues is well beyond the scope of this paper.

${ }^{13}$ For the impact of interest groups on EU climate policy see Michaelowa (1998). 


\section{References}

Achtnicht, M. (2009), German Car Buyers' Willingness to Pay to Reduce CO2 Emissions; ZEW Discussion Paper No. 09-058.

Barclays Capital (2010), A design for life, Monthly Carbon Standard (20.04.2010), London.

Becker, G., M. DeGroot, and J. Marschak (1964), Measuring utility by a single-response sequential method, Behavioral Science 9, 226-236.

Böhringer, C. and C. Vogt (2004), Dismantling of a breakthrough: the Kyoto protocol as symbolic policy, European Journal of Political Economy 20, 597-617.

Brouwer R., Brander L., and Van Beukering P. (2008), "A convenient truth": air travel passengers willingness to pay to offset their $\mathrm{CO}_{2}$ emissions; Climatic Change, Vol. 90, 299-313.

Cai B., T.A. Cameron, and G.R. Gerdes (2008), Distributional Preferences and the Incidence of Costs and Benefits in Climate Change Policy, discussion paper, http://www.uoregon.edu/ cameron/vita/climate_distributional_EAERE_072208_trimm ed.pdf

Carlsson, F, M. Kataria, A. Krupnick, E. Lampi, A. Lofgren, P. Qin, S. Chung, and T. Sterner (2010), Paying for Mitigation. A Multiple Country Study, RFF Discussion Paper 10-33, Resources for the Future, Washington DC.

Champ, P., R. Bishop, and R. Moore, R. (2005), Approaches to mitigating hypothetical bias, Proceedings from 2005 Western Regional Research Project W-1133: Benefits and Costs in Natural Resource Planning, February, Salt Lake City, Utah.

Cherry, T.L. (2001), Mental accounting and other-regarding behaviour: Evidence from the lab, Journal of Economic Psychology 22, 605-615.

Cherry, T.L., P. Frykblom, and J.F. Shogren (2002), Hardnose the Dictator, American Economic Review 92, 1218-1221.

Congleton, R.D. (1992), Political institutions and pollution control, Review of Economics and Statistics 74, 412-421.

Cummings, R.R. and L.O. Taylor (1999), Unbiased Value Estimates for Environmental Goods: A Cheap Talk Design for the Contingent Valuation Method, American Economic Review 83, 649-665.

Endres, A., M. Finus, and F. Lobigs (2000), Symbolische Umweltpolitik im Zeitalter der Globalisierung? - Zur Effektivität internationaler Umweltverträge aus ökonomischer Sicht, Perspektiven der Wirtschaftspolitik 1, 73-91.

European Commission (2008), Impact assessment, Document accompanying the Package of Implementation measures for the EU's objectives on climate change and renewable energy for 2020, SEC(2008) 85/3, Brussels, 23 January 2008, available at: http://ec.europa.eu/energy/climate_actions/doc/2008_res_ia_en.pdf.

Gans, J.S. and V. Groves (2010), Carbon Offset Provision with Guilt-Ridden Consumers (August 12, 2010), available at SSRN: http://ssrn.com/abstract=969494.

Finus M. (2001), Game Theory and International Environmental Cooperation, Edward Elgar, Cheltenham, UK.

Hamilton, K., M. Sjardin, T. Marcello, and G. Xu (2008), Foraging a Frontier: State of the Voluntary Carbon Markets 2008, Ecosystem Marketplace and New Carbon Finance, New York and Washington, DC.

Harrison, G.W. and J.A. List (2004), Field Experiments, Journal of Economic Literature 42, 1009-1055.

Hayes, D., J. Shogren, S.Y. Shin, and J. Kliebenstein (1995), Valuing Food Safety in Experimental Auction Markets, American Journal of Agricultural Economics 77, 40-53. 
Huffman, W., M. Rousu, J.F. Shogren, and A. Tegene, A. (2007), The Effects of Prior Beliefs and Learning on Consumers' Acceptance of Genetically Modified Foods, Journal of Economic Behaviour and Organization 63, 193-206.

Johnson, E. and G.F. Nemet (2010), Willingness to pay for climate policy: a review of estimates, Working Paper Series, La Follette School Working Paper No. 2010-011.

Kotchen, M.J. (2009), Voluntary Provision of Public Goods for Bads: A Theory of Environmental Offsets," Economic Journal, 119, 883-899.

Lee J. and T. Cameron (2008), Popular support for climate change mitigation: Evidence from a general population mail survey, Environmental and Resource Economics 41, 223-248.

List, J. (2003), Using Random nth price Auction to Value Non-Market Goods and Services, Journal of Regulatory Economics 23, 193-205.

Löschel, A., K. Kiehl, P. Heindl, V. Lo, H. Koschel, and S. Koesler (2010), KfW/ZEW CO2 Barometer 2010, Frankfurt, available at: ftp://ftp.zew.de/pub/zewdocs/co2panel/CO2Barometer2010.pdf

Lusk, J.L and J.A. Fox (2003), Value Elicitation in Retail and Laboratory Environments, Economics Letters 79, 27-34.

MacKerron, G.J., C. Egerton, C. Gaskell, A. Parpia, and S. Mourato (2009), Willingness to pay for carbon offset certification and co-benefits among (high-)flying young adults in UK, Energy Policy 37, 1372-1381.

Michaelowa, A. (1998), Impact of interest groups on EU climate policy, European Environment 8, 152-160.

Murphy, J.J., P.G. Allen, T.H. Stevens, and D. Weatherhead (2005), A Meta-Analysis of Hypothetical Bias in Stated Preference Valuation, Environmental and Resource Economics 30, 313-325.

Noussair, C., S. Robin, and B. Ruffieux (2002), Do Consumers not Care about Biotech Foods or Do They Just not Read the Labels? Economics Letters 75, 47-53.

Noussair, C., S. Robin, and B. Ruffieux (2004), Do Consumers Really Refuse to Buy Genetically Modified Food?, The Economic Journal 114, 102-120.

Olar, M., W. Adamowicz, P. Boxall, and G. West (2007), Estimation of the Economic Benefits of Marine Mammal Recovery in the St. Lawrence Estuary. Research Series 2007.05.01, Centre de Rescherche en Économie Agroalimentaire, Université Laval, Quebec.

Shogren, J. (2005), Experimental Methods and Valuation, Handbook of Environmental Economics, Volume II, Edited by K.G. Mäler and J.R. Vincent, Elsevier, 969-1027.

StaLa BWL (2007), Struktur- und Regionaldatenbank, http://www.statistik.badenwuerttemberg.de/, November 2007.

Thomson Reuters (2010), EU carbon emissions, EUA price forecasts to 2020, Carbon Market Weekly (17.05.2010), London, 4-5.

Viscusi W.K. and R. Zeckhauser (2006), The reception and valuation of the risks of climate change: A rational and behavioral blend, Climate Change 77, 141-177. 


\section{Annex I: Descriptive statistics of questionnaires}

Table 3: Socio-economic characteristics of participants - part I

\begin{tabular}{|c|c|c|c|c|}
\hline$\#$ & Variable & State & Frequency abs. & Frequency in $\%$ \\
\hline \multirow[t]{3}{*}{1} & Gender & Male & 99 & 49.00 \\
\hline & & Female & 102 & 50.50 \\
\hline & & No answer & 1 & 0.50 \\
\hline \multirow[t]{7}{*}{2} & Age & $18-25$ & 30 & 14.85 \\
\hline & & $26-35$ & 53 & 26.24 \\
\hline & & $36-45$ & 27 & 13.37 \\
\hline & & $46-55$ & 38 & 18.81 \\
\hline & & $56-65$ & 27 & 13.37 \\
\hline & & $66-75$ & 17 & 8.42 \\
\hline & & No answer & 10 & 4.95 \\
\hline \multirow[t]{5}{*}{3} & Family status & Married & 55 & 27.23 \\
\hline & & Unmarried with partner & 61 & 30.20 \\
\hline & & Single & 62 & 30.69 \\
\hline & & Other & 23 & 11.39 \\
\hline & & No answer & 1 & 0.50 \\
\hline \multirow[t]{6}{*}{4} & Children & 1 & 18 & 8.91 \\
\hline & in household & 2 & 16 & 7.92 \\
\hline & & 3 & 7 & 3.47 \\
\hline & & 4 & 2 & 0.99 \\
\hline & & No & 152 & 75.25 \\
\hline & & No answer & 7 & 3.47 \\
\hline \multirow[t]{6}{*}{5} & Education & University & 94 & 46.53 \\
\hline & & Grammar school & 47 & 23.27 \\
\hline & & Intermediate school & 34 & 16.83 \\
\hline & & Secondary school & 22 & 10.89 \\
\hline & & No graduation & 2 & 0.99 \\
\hline & & No answer & 3 & 1.49 \\
\hline \multirow[t]{6}{*}{6} & Nationality & German & 170 & 84.16 \\
\hline & & Turkish & 6 & 2.97 \\
\hline & & Russian & 1 & 0.50 \\
\hline & & Italian & 2 & 0.99 \\
\hline & & Other & 21 & 10.40 \\
\hline & & No answer & 2 & 0.99 \\
\hline \multirow[t]{7}{*}{7} & Household & Less than $€ 1,000$ & 49 & 24.26 \\
\hline & net income & $€ 1,000-€ 2,000$ & 71 & 35.15 \\
\hline & & $€ 2,000-€ 3,000$ & 38 & 18.81 \\
\hline & & $€ 3,000-€ 4,000$ & 16 & 7.92 \\
\hline & & $€ 4,000-€ 5,000$ & 10 & 4.95 \\
\hline & & More than $€ 5,000$ & 8 & 3.96 \\
\hline & & No answer & 10 & 4.95 \\
\hline \multirow[t]{4}{*}{8} & Religion & Yes & 125 & 61.88 \\
\hline & & No & 76 & 37.62 \\
\hline & & No answer & 1 & 0.50 \\
\hline & & $\sum$ & 202 & 100.00 \\
\hline
\end{tabular}


Table 4: Socio-economic characteristics of participants - part II

\begin{tabular}{|c|c|c|c|c|}
\hline \# & Variable & State & Frequency abs. & Frequency in \% \\
\hline \multirow[t]{8}{*}{9} & Voting & Christian Democratic / Christian Social Union & 33 & 16.34 \\
\hline & behavior & Social Democratic Party & 38 & 18.81 \\
\hline & & Green Party & 47 & 23.27 \\
\hline & & Free Liberal Party & 19 & 9.41 \\
\hline & & Left Party & 12 & 5.94 \\
\hline & & Others & 6 & 2.97 \\
\hline & & Nonvoter & 24 & 11.88 \\
\hline & & No answer & 18 & 8.91 \\
\hline \multirow[t]{11}{*}{10} & Profession & Employee & 77 & 38.12 \\
\hline & & Worker & 4 & 1.98 \\
\hline & & Public Officer & 11 & 5.45 \\
\hline & & Self-employed & 15 & 7.43 \\
\hline & & Apprentice / Trainee & 0 & 0.00 \\
\hline & & Pupil & 2 & 0.99 \\
\hline & & Student / doctoral candidate & 38 & 18.81 \\
\hline & & Retiree & 30 & 14.85 \\
\hline & & Unemployed & 13 & 6.44 \\
\hline & & Others & 9 & 4.46 \\
\hline & & No answer & 3 & 1.49 \\
\hline \multirow[t]{4}{*}{11} & Member of an & Yes & 13 & 6.44 \\
\hline & environmental & No & 185 & 91.58 \\
\hline & organisation & No answer & 4 & 1.98 \\
\hline & & $\Sigma$ & 202 & 100.00 \\
\hline
\end{tabular}


Table 5: Attitudes and experiences with respect to climate change - part I

\begin{tabular}{|c|c|c|c|c|}
\hline \# & Variable & State & Frequency abs. & Frequency in $\%$ \\
\hline \multirow[t]{6}{*}{12} & \multirow{6}{*}{$\begin{array}{l}\text { Please rate your level of } \\
\text { information regarding climate } \\
\text { change. I am... }\end{array}$} & Very poorly informed & 2 & 0.99 \\
\hline & & Rather poorly informed & 14 & 6.93 \\
\hline & & Averagely informed & 104 & 51.49 \\
\hline & & Rather well informed & 66 & 32.67 \\
\hline & & Very well informed & 14 & 6.93 \\
\hline & & No answer & 2 & 0.99 \\
\hline \multirow[t]{6}{*}{13} & \multirow{6}{*}{$\begin{array}{l}\text { To what extent are you influenced } \\
\text { by mass media regarding your } \\
\text { perception of the consequences of } \\
\text { climate change? }\end{array}$} & Not at all influenced & 4 & 1.98 \\
\hline & & Rather not influenced & 21 & 10.40 \\
\hline & & Neutral & 69 & 34.16 \\
\hline & & Rather strong influenced & 92 & 45.54 \\
\hline & & Very strong influenced & 14 & 6.93 \\
\hline & & No answer & 2 & 0.99 \\
\hline \multirow[t]{6}{*}{14} & \multirow{6}{*}{$\begin{array}{l}\text { Are you concerned about climate } \\
\text { change? }\end{array}$} & Not at all concerned & 9 & 4.46 \\
\hline & & Rather not concerned & 26 & 12.87 \\
\hline & & Neutral & 34 & 16.83 \\
\hline & & Rather concerned & 106 & 52.48 \\
\hline & & Very concerned & 25 & 12.38 \\
\hline & & No answer & 2 & 0.99 \\
\hline \multirow[t]{3}{*}{15} & \multirow{3}{*}{$\begin{array}{l}\text { Do you expect noticeable negative } \\
\text { consequences of climate change } \\
\text { for your personal life? }\end{array}$} & Yes & 96 & 47.52 \\
\hline & & No & 104 & 51.49 \\
\hline & & No answer & 2 & 0.99 \\
\hline \multirow[t]{3}{*}{16} & \multirow{3}{*}{$\begin{array}{l}\text { Do you expect noticeable positive } \\
\text { consequences of climate change } \\
\text { for your personal life? }\end{array}$} & Yes & 16 & 7.92 \\
\hline & & No & 182 & 90.10 \\
\hline & & No answer & 4 & 1.98 \\
\hline \multirow[t]{6}{*}{17} & \multirow{6}{*}{$\begin{array}{l}\text { To what extent do you think that } \\
\text { climate change poses a serious } \\
\text { threat to you and your family? }\end{array}$} & No serious threat & 36 & 17.82 \\
\hline & & Rather no serious threat & 52 & 25.74 \\
\hline & & Neutral & 61 & 30.20 \\
\hline & & Rather serious threat & 45 & 22.28 \\
\hline & & Very serious threat & 3 & 1.49 \\
\hline & & No answer & 5 & 2.48 \\
\hline \multirow[t]{6}{*}{17} & \multirow{6}{*}{$\begin{array}{l}\text { To what extent do you think that } \\
\text { climate change poses a serious } \\
\text { threat to your children (if } \\
\text { applicable)? }\end{array}$} & No serious threat & 9 & 4.46 \\
\hline & & Rather no serious threat & 13 & 6.44 \\
\hline & & Neutral & 28 & 13.86 \\
\hline & & Rather serious threat & 60 & 29.70 \\
\hline & & Very serious threat & 16 & 7.92 \\
\hline & & No answer & 76 & 37.62 \\
\hline \multirow[t]{6}{*}{17} & \multirow{6}{*}{$\begin{array}{l}\text { To what extent do you think that } \\
\text { climate change poses a serious } \\
\text { threat to future generations in } \\
\text { general? }\end{array}$} & No serious threat & 5 & 2.48 \\
\hline & & Rather no serious threat & 9 & 4.46 \\
\hline & & Neutral & 16 & 7.92 \\
\hline & & Rather serious threat & 99 & 49.01 \\
\hline & & Very serious threat & 70 & 34.65 \\
\hline & & No answer & 3 & 1.49 \\
\hline \multirow[t]{7}{*}{17} & \multirow{7}{*}{$\begin{array}{l}\text { To what extent do you think that } \\
\text { climate change poses a serious } \\
\text { threat to friends, acquaintances, } \\
\text { colleagues? }\end{array}$} & No serious threat & 24 & 11.88 \\
\hline & & Rather no serious threat & 45 & 22.28 \\
\hline & & Neutral & 70 & 34.65 \\
\hline & & Rather serious threat & 52 & 25.74 \\
\hline & & Very serious threat & 5 & 2.48 \\
\hline & & No answer & 6 & 2.97 \\
\hline & & $\Sigma$ & 202 & 100.00 \\
\hline
\end{tabular}


Table 6: Attitudes and experiences with respect to climate change - part II

\begin{tabular}{|c|c|c|c|c|}
\hline \# & Variable & State & Frequency abs. & Frequency in $\%$ \\
\hline \multirow[t]{6}{*}{17} & \multirow{6}{*}{$\begin{array}{l}\text { To what extent do you think that } \\
\text { climate change poses a serious } \\
\text { threat to people in Germany in } \\
\text { general? }\end{array}$} & No serious threat & 23 & 11.39 \\
\hline & & Rather no serious threat & 37 & 18.32 \\
\hline & & Neutral & 69 & 34.16 \\
\hline & & Rather serious threat & 60 & 29.70 \\
\hline & & Very serious threat & 8 & 3.96 \\
\hline & & No answer & 5 & 2.48 \\
\hline \multirow[t]{6}{*}{17} & \multirow{6}{*}{$\begin{array}{l}\text { To what extent do you think that } \\
\text { climate change poses a serious } \\
\text { threat to people in other } \\
\text { industrialized countries? }\end{array}$} & No serious threat & 11 & 5.45 \\
\hline & & Rather no serious threat & 30 & 14.85 \\
\hline & & Neutral & 49 & 24.26 \\
\hline & & Rather serious threat & 80 & 39.60 \\
\hline & & Very serious threat & 25 & 12.38 \\
\hline & & No answer & 7 & 3.47 \\
\hline \multirow[t]{6}{*}{17} & \multirow{6}{*}{$\begin{array}{l}\text { To what extent do you think that } \\
\text { climate change poses a serious } \\
\text { threat to people in developing } \\
\text { countries? }\end{array}$} & No serious threat & 4 & 1.98 \\
\hline & & Rather no serious threat & 5 & 2.48 \\
\hline & & Neutral & 13 & 6.44 \\
\hline & & Rather serious threat & 69 & 34.16 \\
\hline & & Very serious threat & 105 & 51.98 \\
\hline & & No answer & 6 & 2.97 \\
\hline \multirow[t]{3}{*}{18} & \multirow{3}{*}{$\begin{array}{l}\text { Have you been personally affected } \\
\text { by negative effects of climate } \\
\text { change? }\end{array}$} & Yes & 18 & 8.91 \\
\hline & & No & 181 & 89.60 \\
\hline & & No answer & 2 & 0.99 \\
\hline \multirow[t]{3}{*}{21} & \multirow{3}{*}{$\begin{array}{l}\text { Have you been personally affected } \\
\text { by positive effects of climate } \\
\text { change? }\end{array}$} & Yes & 8 & 3.96 \\
\hline & & No & 191 & 94.55 \\
\hline & & No answer & 3 & 1.49 \\
\hline \multirow[t]{7}{*}{24} & \multirow{7}{*}{$\begin{array}{l}\text { When do you expect the impacts } \\
\text { of climate change to become } \\
\text { visible? }\end{array}$} & Never & 6 & 2.97 \\
\hline & & In more than 100 years & 10 & 4.95 \\
\hline & & Within the next 100 years & 16 & 7.92 \\
\hline & & Within the next 50 years & 55 & 27.23 \\
\hline & & Within the next 10 years & 23 & 11.39 \\
\hline & & Already visible & 83 & 41.09 \\
\hline & & No answer & 9 & 4.46 \\
\hline \multirow[t]{5}{*}{25} & \multirow{5}{*}{$\begin{array}{l}\text { Do you think that there still is a } \\
\text { need for commitment to fight } \\
\text { climate change? }\end{array}$} & Yes & 175 & 86.63 \\
\hline & & No & 13 & 6.44 \\
\hline & & Don't know & 12 & 5.94 \\
\hline & & No answer & 2 & 0.99 \\
\hline & & $\Sigma$ & 202 & 100.00 \\
\hline
\end{tabular}


Table 7: Attitudes and experiences with respect to climate change - part III

\begin{tabular}{|c|c|c|c|c|}
\hline$\#$ & Variable & State & Frequency abs. & Frequency in \% \\
\hline \multirow[t]{6}{*}{26} & \multirow{6}{*}{$\begin{array}{l}\text { To what extent do you agree to the } \\
\text { statement: I believe my personal } \\
\text { behavior has an influence on climate } \\
\text { change? }\end{array}$} & Do not agree & 9 & 4.46 \\
\hline & & Rather not agree & 28 & 13.86 \\
\hline & & Don't know & 19 & 9.41 \\
\hline & & Rather agree & 100 & 49.50 \\
\hline & & Fully agree & 41 & 20.30 \\
\hline & & No answer & 5 & 2.48 \\
\hline \multirow[t]{6}{*}{26} & \multirow{6}{*}{$\begin{array}{l}\text { To what extent do you agree to the } \\
\text { statement: My behavior to evade climate } \\
\text { change can encourage others in my } \\
\text { environment to behave the same way? }\end{array}$} & Do not agree & 7 & 3.47 \\
\hline & & Rather not agree & 15 & 7.43 \\
\hline & & Don't know & 28 & 13.86 \\
\hline & & Rather agree & 101 & 50.00 \\
\hline & & Fully agree & 48 & 23.76 \\
\hline & & No answer & 3 & 1.49 \\
\hline \multirow[t]{6}{*}{26} & \multirow{6}{*}{$\begin{array}{l}\text { To what extent do you agree to the } \\
\text { statement: The government is solely } \\
\text { responsible for measures against climate } \\
\text { change? }\end{array}$} & Do not agree & 95 & 47.03 \\
\hline & & Rather not agree & 72 & 35.64 \\
\hline & & Don't know & 10 & 4.95 \\
\hline & & Rather agree & 14 & 6.93 \\
\hline & & Fully agree & 7 & 3.47 \\
\hline & & No answer & 4 & 1.98 \\
\hline \multirow[t]{6}{*}{26} & \multirow{6}{*}{$\begin{array}{l}\text { To what extent do you agree to the } \\
\text { statement: To mitigate climate change } \\
\text { every German citizen should use as little } \\
\text { electricity as possible? }\end{array}$} & Do not agree & 5 & 2.48 \\
\hline & & Rather not agree & 26 & 12.87 \\
\hline & & Don't know & 33 & 16.34 \\
\hline & & Rather agree & 99 & 49.01 \\
\hline & & Fully agree & 35 & 17.33 \\
\hline & & No answer & 4 & 1.98 \\
\hline \multirow[t]{7}{*}{26} & \multirow{7}{*}{$\begin{array}{l}\text { To what extent do you agree to the } \\
\text { statement: To mitigate climate change } \\
\text { every German citizen should use their } \\
\text { car as a means of transport as little as } \\
\text { possible? }\end{array}$} & Do not agree & 3 & 1.49 \\
\hline & & Rather not agree & 25 & 12.38 \\
\hline & & Don't know & 13 & 6.44 \\
\hline & & Rather agree & 94 & 46.53 \\
\hline & & Fully agree & 64 & 31.68 \\
\hline & & No answer & 3 & 1.49 \\
\hline & & $\Sigma$ & 202 & 100.00 \\
\hline
\end{tabular}

Table 8: Price appraisals

\begin{tabular}{lllrr}
\hline$\#$ & Variable & State & Frequency abs. & Frequency in \% \\
\hline 27 & Summary of the price & $<€ 1$ & 39 & 19.31 \\
& estimations & $€ 1-€ 2$ & 25 & 12.38 \\
& (for 1 unit = 100 kg CO 2$)$ & $€ 2-€ 10$ & 66 & 32.67 \\
& & $€ 10-€ 100$ & 39 & 19.31 \\
& & $>€ 100$ & 20 & 9.90 \\
& & No answer & 13 & 6.44 \\
\cline { 3 - 5 } 28 & How sure are you about your & I know it & 4 & 1.98 \\
& price estimation? & Sure & 0 & 0.00 \\
& & Rather sure & 5 & 2.48 \\
& & Rather unsure & 48 & 23.76 \\
& & I don't know, I guessed & 135 & 66.83 \\
& & No answer & 10 & 4.95 \\
\cline { 3 - 5 } 29 & Will you talk about this & Yes & 167 & 82.67 \\
& event and your behavior in it & No & 5 & 2.48 \\
& with your family, your & Don't know & 27 & 13.37 \\
friends or your colleagues? & No answer & 3 & 1.49 \\
\cline { 3 - 5 } & & & 202 & 100.00 \\
\hline \multirow{2}{*}{} & & & &
\end{tabular}


Table 9: Buying motives of participants - part I

\begin{tabular}{|c|c|c|c|c|}
\hline$\#$ & Variable & State & Frequency abs. & Frequency in $\%$ \\
\hline \multirow[t]{6}{*}{30} & I want to buy certificates, because & Absolutely not applicable & 2 & 1.68 \\
\hline & I want to contribute to climate & Rather not applicable & 3 & 2.52 \\
\hline & protection - regardless of what & Neutral & 13 & 10.92 \\
\hline & others do. & Rather applicable & 48 & 40.34 \\
\hline & & Absolutely applicable & 52 & 43.70 \\
\hline & & No answer & 1 & 0.84 \\
\hline \multirow[t]{6}{*}{30} & I want to buy certificates, because & Absolutely not applicable & 11 & 9.24 \\
\hline & I think that others also contribute & Rather not applicable & 11 & 9.24 \\
\hline & to climate protection. & Neutral & 30 & 25.21 \\
\hline & & Rather applicable & 52 & 43.70 \\
\hline & & Absolutely applicable & 14 & 11.76 \\
\hline & & No answer & 1 & 0.84 \\
\hline \multirow[t]{6}{*}{30} & I want to buy certificates, because & Absolutely not applicable & 2 & 1.68 \\
\hline & especially people in poor & Rather not applicable & 11 & 9.24 \\
\hline & countries will suffer from the & Neutral & 17 & 14.29 \\
\hline & consequences of climate change & Rather applicable & 56 & 47.06 \\
\hline & and I want to do something & Absolutely applicable & 32 & 26.89 \\
\hline & against it. & No answer & 1 & 0.84 \\
\hline \multirow[t]{6}{*}{30} & I want to buy certificates, because & Absolutely not applicable & 3 & 2.52 \\
\hline & the industrialized countries, & Rather not applicable & 13 & 10.92 \\
\hline & among them Germany, have & Neutral & 25 & 21.01 \\
\hline & played a decisive role in causing & Rather applicable & 50 & 42.02 \\
\hline & climate change. & Absolutely applicable & 26 & 21.85 \\
\hline & & No answer & 2 & 1.68 \\
\hline \multirow[t]{6}{*}{30} & I want to buy certificates, because & Absolutely not applicable & 2 & 1.68 \\
\hline & future generations will suffer & Rather not applicable & 6 & 5.04 \\
\hline & from the consequences of climate & Neutral & 11 & 9.24 \\
\hline & change and I want to do & Rather applicable & 52 & 43.70 \\
\hline & something against it. & Absolutely applicable & 46 & 38.66 \\
\hline & & No answer & 2 & 1.68 \\
\hline \multirow[t]{7}{*}{30} & I want to buy certificates, because & Absolutely not applicable & 4 & 3.36 \\
\hline & the flora and fauna will suffer & Rather not applicable & 8 & 6.72 \\
\hline & from the consequences. & Neutral & 16 & 13.45 \\
\hline & & Rather applicable & 59 & 49.58 \\
\hline & & Absolutely applicable & 31 & 26.05 \\
\hline & & No answer & 1 & 0.84 \\
\hline & & $\Sigma$ & 119 & 100.00 \\
\hline
\end{tabular}


Table 10: Buying motives of participants - part II

\begin{tabular}{|c|c|c|c|c|}
\hline \# & Variable & State & Frequency abs. & Frequency in $\%$ \\
\hline \multirow[t]{6}{*}{30} & \multirow{6}{*}{$\begin{array}{l}\text { I want to buy certificates, because } \\
\text { the government is not doing } \\
\text { enough against climate change. }\end{array}$} & Absolutely not applicable & 5 & 4.20 \\
\hline & & Rather not applicable & 23 & 19.33 \\
\hline & & Neutral & 32 & 26.89 \\
\hline & & Rather applicable & 35 & 29.41 \\
\hline & & Absolutely applicable & 23 & 19.33 \\
\hline & & No answer & 1 & 0.84 \\
\hline \multirow[t]{6}{*}{30} & \multirow{6}{*}{$\begin{array}{l}\text { I want to buy certificates, because } \\
\text { my environment (family, friends, } \\
\text { colleagues) expect me to. }\end{array}$} & Absolutely not applicable & 53 & 44.54 \\
\hline & & Rather not applicable & 32 & 26.89 \\
\hline & & Neutral & 20 & 16.81 \\
\hline & & Rather applicable & 12 & 10.08 \\
\hline & & Absolutely applicable & 1 & 0.84 \\
\hline & & No answer & 1 & 0.84 \\
\hline \multirow[t]{6}{*}{30} & \multirow{6}{*}{$\begin{array}{l}\text { I want to buy certificates, because } \\
\text { the organizers of this event expect } \\
\text { me to. }\end{array}$} & Absolutely not applicable & 76 & 63.87 \\
\hline & & Rather not applicable & 16 & 13.45 \\
\hline & & Neutral & 19 & 15.97 \\
\hline & & Rather applicable & 6 & 5.04 \\
\hline & & Absolutely applicable & 1 & 0.84 \\
\hline & & No answer & 1 & 0.84 \\
\hline \multirow[t]{6}{*}{30} & \multirow{6}{*}{$\begin{array}{l}\text { I want to buy certificates, because } \\
\text { it is my moral obligation. }\end{array}$} & Absolutely not applicable & 23 & 19.33 \\
\hline & & Rather not applicable & 12 & 10.08 \\
\hline & & Neutral & 25 & 21.01 \\
\hline & & Rather applicable & 48 & 40.34 \\
\hline & & Absolutely applicable & 10 & 8.40 \\
\hline & & No answer & 1 & 0.84 \\
\hline \multirow[t]{7}{*}{30} & \multirow{7}{*}{$\begin{array}{l}\text { I want to buy certificates, because } \\
\text { it is important to protect the } \\
\text { creation. }\end{array}$} & Absolutely not applicable & 16 & 13.45 \\
\hline & & Rather not applicable & 14 & 11.76 \\
\hline & & Neutral & 36 & 30.25 \\
\hline & & Rather applicable & 36 & 30.25 \\
\hline & & Absolutely applicable & 16 & 13.45 \\
\hline & & No answer & 1 & 0.84 \\
\hline & & $\Sigma$ & 119 & 100.00 \\
\hline
\end{tabular}


Table 11: Refusing motives of participants

\begin{tabular}{|c|c|c|c|c|}
\hline \# & Variable & State & Frequency abs. & Frequency in \% \\
\hline \multirow[t]{6}{*}{31} & \multirow{6}{*}{$\begin{array}{l}\text { I do not want to buy certificates, } \\
\text { because I do not think that my } \\
\text { buying of certificates will actually } \\
\text { reduce emissions in Europe. }\end{array}$} & Absolutely not applicable & 7 & 8.43 \\
\hline & & Rather not applicable & 4 & 4.82 \\
\hline & & Neutral & 3 & 3.61 \\
\hline & & Rather applicable & 23 & 27.71 \\
\hline & & Absolutely applicable & 20 & 24.10 \\
\hline & & No answer & 26 & 31.33 \\
\hline \multirow[t]{6}{*}{31} & \multirow{6}{*}{$\begin{array}{l}\text { I do not want to buy certificates, } \\
\text { because a market for certificates } \\
\text { does not work. We need official } \\
\text { prohibitions and commands. }\end{array}$} & Absolutely not applicable & 5 & 6.02 \\
\hline & & Rather not applicable & 6 & 7.23 \\
\hline & & Neutral & 8 & 9.64 \\
\hline & & Rather applicable & 22 & 26.51 \\
\hline & & Absolutely applicable & 12 & 14.46 \\
\hline & & No answer & 30 & 36.14 \\
\hline \multirow[t]{6}{*}{31} & \multirow{6}{*}{$\begin{array}{l}\text { I do not want to buy certificates, } \\
\text { because I already act in a climate } \\
\text { conscious way. }\end{array}$} & Absolutely not applicable & 1 & 1.20 \\
\hline & & Rather not applicable & 3 & 3.61 \\
\hline & & Neutral & 14 & 16.87 \\
\hline & & Rather applicable & 18 & 21.69 \\
\hline & & Absolutely applicable & 17 & 20.48 \\
\hline & & No answer & 30 & 36.14 \\
\hline \multirow[t]{6}{*}{31} & \multirow{6}{*}{$\begin{array}{l}\text { I do not want to buy certificates, } \\
\text { because emissions trading } \\
\text { anyhow suits the interests of the } \\
\text { large scale industry only. }\end{array}$} & Absolutely not applicable & 3 & 3.61 \\
\hline & & Rather not applicable & 10 & 12.05 \\
\hline & & Neutral & 12 & 14.46 \\
\hline & & Rather applicable & 24 & 28.92 \\
\hline & & Absolutely applicable & 6 & 7.23 \\
\hline & & No answer & 28 & 33.73 \\
\hline \multirow[t]{6}{*}{31} & \multirow{6}{*}{$\begin{array}{l}\text { I do not want to buy certificates, } \\
\text { because I think that emissions } \\
\text { trading is principally unethical. }\end{array}$} & Absolutely not applicable & 14 & 16.87 \\
\hline & & Rather not applicable & 8 & 9.64 \\
\hline & & Neutral & 16 & 19.28 \\
\hline & & Rather applicable & 12 & 14.46 \\
\hline & & Absolutely applicable & 5 & 6.02 \\
\hline & & No answer & 28 & 33.73 \\
\hline \multirow[t]{6}{*}{31} & \multirow{6}{*}{$\begin{array}{l}\text { I do not want to buy certificates, } \\
\text { because I would buy certificates } \\
\text { from companies which have } \\
\text { received them for free and by that } \\
\text { subsidy them. }\end{array}$} & Absolutely not applicable & 5 & 6.02 \\
\hline & & Rather not applicable & 9 & 10.84 \\
\hline & & Neutral & 21 & 25.30 \\
\hline & & Rather applicable & 14 & 16.87 \\
\hline & & Absolutely applicable & 4 & 4.82 \\
\hline & & No answer & 30 & 36.14 \\
\hline \multirow[t]{6}{*}{31} & \multirow{6}{*}{$\begin{array}{l}\text { I do not want to buy certificates, } \\
\text { because I do not trust ZEW. }\end{array}$} & Absolutely not applicable & 29 & 34.94 \\
\hline & & Rather not applicable & 11 & 13.25 \\
\hline & & Neutral & 8 & 9.64 \\
\hline & & Rather applicable & 4 & 4.82 \\
\hline & & Absolutely applicable & 2 & 2.41 \\
\hline & & No answer & 29 & 34.94 \\
\hline \multirow[t]{7}{*}{31} & \multirow{7}{*}{$\begin{array}{l}\text { I do not want to buy certificates, } \\
\text { because I do not think that } \\
\text { emissions can actually be } \\
\text { measured and controlled. }\end{array}$} & Absolutely not applicable & 12 & 14.46 \\
\hline & & Rather not applicable & 11 & 13.25 \\
\hline & & Neutral & 15 & 18.07 \\
\hline & & Rather applicable & 9 & 10.84 \\
\hline & & Absolutely applicable & 6 & 7.23 \\
\hline & & No answer & 30 & 36.14 \\
\hline & & $\sum$ & 83 & 100.00 \\
\hline
\end{tabular}




\section{Annex II: Transcript of written instructions}

\section{Instructions}

Welcome to the Centre for European Economic Research (ZEW) in Mannheim!

Thank you for participating in this scientific survey about consumer decisions. In this file you will find all information you will need during the survey. During the event you will have the opportunity to return to the previous pages. But please do not read the upcoming pages unless we ask you to.

Please follow the instructions attentively and please do not talk to the other participants.

Please be assured that the data we collect today will only be used to compare results between groups of participants. We will not publish any individual data of the participants.

ID: $1 \mathrm{~S} 1$ 


\section{Questionnaire I}

Please answer the following questions by ticking the according box or filling the blanks.

General questions

1. Please state your marital status:

Married

$\mathrm{O}$

Unmarried with partner

$\mathrm{O}$

Single

$\mathrm{O}$

Other

$\mathrm{O}$

2. Please state your sex:

Male

$\mathrm{O}$

Female

$\mathrm{O}$

3. Please state your age:

4. Are you a member of a religious community?

Yes

$\mathrm{O}$

No

$\mathrm{O}$

5. How many children live in your household? (If you do not have any children please fill out all age groups with a 0 )

$0-3$ years

4-7 years

8-12 years

13-18 years

Older than 18

6. Please state the institution at which you have acquired your highest professional degree:

University/University of Applied Sciences O

Grammar School $\quad$ O

Intermediate School O

Secondary School O

None

$\mathrm{O}$

7. Please state your nationality of origin:

German

$\mathrm{O}$

Turkish

$\mathrm{O}$

Russian

$\mathrm{O}$

Italian

$\mathrm{O}$

Other, (please state): 
8. How much money is available in your household per month (net income)?

$\begin{array}{ll}\text { Less than } € 1,000 & \mathrm{O} \\ € 1,000-€ 2,000 & \mathrm{O} \\ € 2,000-€ 3,000 & \mathrm{O} \\ € 3,000-€ 4,000 & \mathrm{O} \\ € 4,000-€ 5,000 & \mathrm{O} \\ \text { More than } € 5,000 & \mathrm{O} \\ \text { No comment } & \mathrm{O}\end{array}$

9. If Sunday were Election Day, which party would you vote for? CDU/CSU - Christian Democratic Union/Christian Social Union SPD - Social Democratic Party

Alliance 90/ Green Party

$\mathrm{O}$

$\mathrm{O}$

$\mathrm{O}$

$\mathrm{O}$

$\mathrm{O}$

$\mathrm{O}$

$\mathrm{O}$

$\mathrm{O}$

10. Please state your professional occupation

$\begin{array}{ll}\text { Employee } & \mathrm{O} \\ \text { Worker } & \mathrm{O} \\ \text { Unemployed } & \mathrm{O} \\ \text { Apprentice/Trainee } & \mathrm{O} \\ \text { Public officer } & \mathrm{O} \\ \text { Pupil } & \mathrm{O} \\ \text { Self-employed } & \mathrm{O} \\ \text { Student/ doctoral candidate } & \mathrm{O} \\ \quad \text { Retiree } & \mathrm{O} \\ \text { Others } & \mathrm{O}\end{array}$

11. Are you a member of an initiative or organisation promoting environmental protection?

Yes $\mathrm{O}$

No $\mathrm{O}$

\section{Climate Change Questions}

ZEW carries out research projects on climate change. Therefore, we would like to ask you to answer some questions on climate change.

12. Please rate your level of information regarding climate change. I am...

\begin{tabular}{|c|c|c|c|c|}
\hline $\begin{array}{c}\text { Very poorly } \\
\text { informed }\end{array}$ & $\begin{array}{c}\text { Rather poorly } \\
\text { informed }\end{array}$ & Averagely informed & $\begin{array}{c}\text { Rather well } \\
\text { informed }\end{array}$ & $\begin{array}{c}\text { Very well } \\
\text { informed }\end{array}$ \\
\hline & & & & \\
\hline
\end{tabular}

13. To what extent are you influenced by mass media (newspapers, TV, internet) regarding your perception of the consequences of climate change?

\begin{tabular}{|c|c|c|c|c|}
\hline $\begin{array}{c}\text { Not at all } \\
\text { influenced }\end{array}$ & $\begin{array}{c}\text { Rather not } \\
\text { influenced }\end{array}$ & Neutral & $\begin{array}{c}\text { Rather strongly } \\
\text { influenced }\end{array}$ & $\begin{array}{c}\text { Very strongly } \\
\text { influenced }\end{array}$ \\
\hline & & & & \\
\hline
\end{tabular}

14. Are you concerned about climate change?

\begin{tabular}{|c|c|c|c|c|}
\hline $\begin{array}{c}\text { Not at all } \\
\text { concerned }\end{array}$ & $\begin{array}{l}\text { Rather not } \\
\text { concerned }\end{array}$ & Neutral & Rather concerned & Very concerned \\
\hline & & & & \\
\hline
\end{tabular}


15. Do you expect noticeable negative consequences of climate change for your personal life? Yes $\mathrm{O}$

No $\quad \mathrm{O}$

16. Do you expect noticeable positive consequences of climate change for your personal life?

Yes $\mathrm{O}$

No $\quad \mathrm{O}$

17. To what extent do you think that climate change poses a serious threat to the respective areas?

\begin{tabular}{|l|l|l|l|l|l|}
\hline Area $\downarrow$ & $\begin{array}{c}\text { No serious } \\
\text { threat }\end{array}$ & $\begin{array}{c}\text { Rather no } \\
\text { serious } \\
\text { threat }\end{array}$ & Neutral & $\begin{array}{c}\text { Rather } \\
\text { serious } \\
\text { threat }\end{array}$ & $\begin{array}{c}\text { Very } \\
\text { serious } \\
\text { threat }\end{array}$ \\
\hline For me and my family & & & & & \\
\hline For my children (if applicable) & & & & & \\
\hline Future generations in general & & & & & \\
\hline $\begin{array}{l}\text { Friends, acquaintances, } \\
\text { colleagues }\end{array}$ & & & & & \\
\hline People in Germany in general & & & & & \\
\hline $\begin{array}{l}\text { People in other industrialised } \\
\text { countries }\end{array}$ & & & & & \\
\hline People in developing countries & & & & & \\
\hline
\end{tabular}

18. Have you been personally affected by negative effects of climate change?

Yes $\mathrm{O}$

No $\quad$ O (if no, please proceed to question 21)

19. If yes, which effects?

20. How strong were these negative effects for you personally?

\begin{tabular}{|c|c|c|c|c|}
\hline Very weak & Rather weak & Neutral & Rather strong & Very strong \\
\hline
\end{tabular}

21. Have you been personally affected by positive effects of climate change?

Yes $\mathrm{O}$

No $\quad$ O (if no, please proceed to question 24)

22. If yes, which effects?

23. How strong were these positive effects for you personally?

\begin{tabular}{|c|c|c|c|c|}
\hline Very weak & Rather weak & Neutral & Rather strong & Very strong \\
\hline & & & & \\
\hline
\end{tabular}


24. When do you expect the impacts of climate change to become visible?

\begin{tabular}{|c|c|c|c|c|c|}
\hline Never & $\begin{array}{c}\text { In more than } \\
100 \text { years }\end{array}$ & $\begin{array}{c}\text { Within the next } \\
100 \text { years }\end{array}$ & $\begin{array}{c}\text { Within the next } \\
50 \text { years }\end{array}$ & $\begin{array}{c}\text { Within the next } \\
10 \text { years }\end{array}$ & Already visible \\
\hline & & & & & \\
\hline
\end{tabular}

25. Do you think that there still is a need for commitment to fight climate change?

$\begin{array}{ll}\text { Yes } & \mathrm{O} \\ \text { No } & \mathrm{O} \\ \text { Don't know } & \mathrm{O}\end{array}$

26. To which extent do you agree to the following statements?

\begin{tabular}{|l|l|l|l|l|l|}
\hline Statement $\downarrow$ & $\begin{array}{c}\text { Do not } \\
\text { agree }\end{array}$ & $\begin{array}{c}\text { Rather not } \\
\text { agree }\end{array}$ & $\begin{array}{c}\text { Don't } \\
\text { know }\end{array}$ & $\begin{array}{c}\text { Rather } \\
\text { agree }\end{array}$ & $\begin{array}{c}\text { Fully } \\
\text { agree }\end{array}$ \\
\hline $\begin{array}{l}\text { I believe my personal behavior has } \\
\text { influence on climate change. }\end{array}$ & & & & & \\
\hline $\begin{array}{l}\text { My behavior to evade climate change } \\
\text { can encourage others in my } \\
\text { environment to behave the same way. }\end{array}$ & & & & & \\
\hline $\begin{array}{l}\text { The government is solely responsible } \\
\text { for measures against climate change. }\end{array}$ & & & & & \\
\hline $\begin{array}{l}\text { To mitigate climate change every } \\
\text { German citizen should use as little } \\
\text { electricity as possible. }\end{array}$ & & & & & \\
\hline $\begin{array}{l}\text { To mitigate climate change every } \\
\text { German citizen should use their car } \\
\text { as a means of transport as little as } \\
\text { possible. }\end{array}$ & & & & & \\
\hline
\end{tabular}




\section{General Information}

Today, we will offer you a certain product to purchase. In a few minutes you will learn which product it is and how the sale will be conducted. No one except for the ZEW team will learn about your statements from the event.

As we want to assess how many units of the product you want to purchase, we would like to ask you not to talk to the other participants.

Should you have any questions please signal us and we will come to you.

The process of sale can be explained in three steps:

\section{Introduction of the product}

Before we ask you to make a purchase offer we will briefly introduce the product to you.

\section{Quantity you want to buy with different pricing}

You will receive a list with five prices for one unit of the product. You can state the quantity you want to purchase at the respective price. You can also state the quantity zero if you do not wish to purchase anything (there is no obligation to buy). At the end of the event you will draw one of the prices by lot. You will then buy the chosen quantity at the drawn price.

\section{Payment}

When leaving the room you will draw one price. You will then buy the quantity you have stated at this price. Please note: If you purchase the product, you have to use your own money (but: your expenditures cannot exceed $€ 40$ ).

Soon we will discuss a short example with you.

Please note:

With these rules of purchase it is in your own interest to state only the quantity you actually want to buy at the respective prices. Please state only truthful information. 


\section{Comprehension Test}

We will now carry out a short test to check if you have fully understood the rules of purchase. To answer the questions please fill in the blank or tick the box next to the question. Please signal if you have finished answering all questions and we will come to you.

Please take a look to the statements in the following table. A participant has stated how many units of the product he wants to buy if the respective price is drawn.

Please note:

The maximum expenditures for each price are $€ 10$ in this example.

\begin{tabular}{|c|c|c|c|c|}
\hline No. & $\begin{array}{c}\text { Price per } \\
\text { unit }\end{array}$ & $\begin{array}{c}\text { How many units do I want to } \\
\text { buy at this price? }\end{array}$ & $\begin{array}{c}\text { How many units can I buy } \\
\text { in total at this price? }\end{array}$ & $\begin{array}{c}\text { Expenditures }= \\
\text { Price x Units }\end{array}$ \\
\hline 1 & $€ 5.00$ & 0 & 2 & $€ 0.00$ \\
\hline 2 & $€ 4.00$ & 0 & 2 & $€ 0.00$ \\
\hline 3 & $€ 3.00$ & 1 & 3 & $€ 3.00$ \\
\hline 4 & $€ 1.00$ & 3 & 10 & $€ 3.00$ \\
\hline 5 & $€ 0.50$ & 4 & 20 & $€ 2.00$ \\
\hline
\end{tabular}

Q: How many units will the participant buy if price no. 2 is drawn? units.

Q: How many units will the participant buy if price no. 5 is drawn? units.

Q: Which amount in Euros will the participant pay if price 3 is drawn?

$€$

What do I have to do, if I do not want to purchase the product at a certain price?

I state any quantity and hope that this price is not drawn

$\mathrm{O}$

I state the quantity zero.

$\mathrm{O}$

What do I have to do if I want to buy exactly three units of the product at a certain price?
a) I state more than three units at this price.
b) I state less than three units at this price.
$\mathrm{O}$
c) I state three units at this price.
$\mathrm{O}$
$\mathrm{O}$ 


\section{Information on Climate Change}

Please read the information provided on this page.

You have about 10 minutes to do so.

Global climate change is seen as a serious environmental problem faced by mankind. The great majority of climate scientists expects the global average temperature to rise by 1.1 to 6.4 degrees Celsius until the year 2100. There is hardly any denial that mankind largely contributes to climate change by emitting greenhouse gases, especially carbon dioxide $\left(\mathrm{CO}_{2}\right) \cdot \mathrm{CO}_{2}$ originates from burning of fossil fuels like coal, oil or natural gas in industrial processes and energy production, or combustion engines of cars and lorries. $\mathrm{CO}_{2}$ is a global pollutant, i.e. each quantity unit of $\mathrm{CO}_{2}$ emitted has the same effect on the climate regardless of the location where the emission has occurred. There are several consequences from rising temperatures. The most important consequences will be stated here:

The sea level will rise by $\mathbf{1 8}$ to $\mathbf{5 9} \mathbf{~ c m}$ worldwide until the year 2100. Low lying coastal regions may be threatened by floods.

Extreme weather events like extreme heat waves, strong rainfalls and tropical storms are likely to become more frequent.

Due to the shift of climate zones pathogens can spread to more northern areas than before. In southern Italy several cases of dengue fever were reported. Dengue fever is a dangerous infectious disease which usually occurs in tropical areas only.

Climate change does not only have negative consequences, but also positive effects. The number of heat-related deaths might increase because of more frequent periods of heat. However, due to milder winters there will be a lower number of deaths by extreme cold.

The consequences of climate change will vary regionally resulting in substantial consequences for agriculture. Countries in the south which today are already hot and dry will become even hotter and dryer. Especially African countries will have to expect lower crop yields. Countries in the north might profit from climate change. In Canada and the northern parts of the USA higher crop yields can be expected.

Briefly summarised: in Germany the following effects can be expected: Until 2050 the mean temperature will rise by $\mathbf{1 . 2 5}$ to $\mathbf{1 . 5}$ degrees Celsius. Winters will become milder and more humid and summers will be hotter and dryer.

Sources used:

Intergovernmental Panel on Climate Change (IPCC)

German Federal Environment Agency (Umweltbundesamt)

World Health Organization(WHO) 


\section{Information on European Emissions Trading}

Please read the information provided on this page.

You will have about 10 minutes to do so.

In 2005 the European Union has implemented the emissions trading system for carbon dioxide $\left(\mathrm{CO}_{2}\right)$. Emissions trading is the central instrument of climate policy in Europe. It follows a simple principle: The European Commission, together with the member states, has determined the amount of $\mathrm{CO}_{2}$ to be emitted altogether in the respective sectors (energy production and energy intensive industries) until 2020. This total amount will be distributed to the companies by the state in the form of emission rights ("permits"). For each quantity unit of $\mathrm{CO}_{2}$ emitted, the company has to give a permit to the state. The permits can be traded between companies.

For each quantity unit of $\mathrm{CO}_{2}$ emitted e.g. by a power plant, the plant operator has to prove his permission to do so in the form of a permit. This leads to an important consequence: If the total amount of permits is reduced, the total emissions will be lower, simply because plant operators do not possess enough emission allowances. That means if a permit for one quantity unit is obtained from the market and is being "retired" (i.e. deleted) the total $\mathbf{C O}_{2}$ emissions are reduced by exactly this quantity amount. The opportunity to retire permits actually exists in the framework of the EU Emissions Trading System. In Germany the German Emissions Trading Authority (DEHSt) regulates Emissions trading. The authority holds a retirement account with the account number DE-230-17-1. If permits are transferred to this account they will be withdrawn from circulation, i.e. deleted, by the end of each year.

Emissions trading has one central advantage: It guarantees that the abatement of $\mathrm{CO}_{2}$ emissions occurs where it is the cheapest option. Companies with opportunities to abate carbon in a costefficient way will sell their permits on the market, whereas companies with high abatement costs can acquire permits at a relatively low price. This trade is beneficiary for both sides and guarantees for the emission reduction target to be achieved at minimal costs.

Altogether, European energy producers and energy intensive industries were allowed to emit about two billion tons of $\mathbf{C O}_{2}$ in the year 2009. As a benchmark: global $\mathrm{CO}_{2}$ emissions per year amount for 29 billion tons of $\mathrm{CO}_{2}$.

Summarising, it can be stated that if the total amount of permits in the EU Emissions Trading System is reduced, the total $\mathrm{CO}_{2}$ emissions in Europe decrease. 


\section{Purchase of $\mathrm{CO}_{2}$ Permits}

\section{Explanation}

You are given the opportunity to buy permits of the EU Emissions Trading System at this event.

ZEW will buy the amount of permits chosen and will retire them. Thus, you have the opportunity to contribute to the reduction of the actual $\mathrm{CO}_{2}$ emissions in Europe.

The purchase of the permits will be attested by an independent body. The amount of permits purchased by each participant will be published on the ZEW website displaying the participant number (no names will be displayed).

\section{If you wish, ZEW will issue an official record about the amount of your permits} purchased at the end of the event.

Introduction of the product " $\mathrm{CO}_{2}$ permits".

One unit equals 100 kilograms of $\mathrm{CO}_{2}$

Quantity you want to buy at each price.

Please state in the table below the quantity of units (100 kg each) you are willing to buy at each price. When leaving the room you will draw by lot one of the five prices. You will then buy the quantity of units you have stated at this price.

Important note: There is no obligation to buy!

Permits purchased have to be paid!

Please note:

Your maximum expenditures for each price are $€ 40$.

\begin{tabular}{|c|c|c|c|c|}
\hline \multicolumn{6}{|c|}{ The unit is $100 \mathrm{~kg}$ of $\mathrm{CO}_{2}$} \\
\hline No. & $\begin{array}{c}\text { Price per } \\
\text { unit }\end{array}$ & $\begin{array}{c}\text { How many units do I want to } \\
\text { buy at this price? }\end{array}$ & $\begin{array}{c}\text { How many units can I buy } \\
\text { in total at this price? }\end{array}$ & $\begin{array}{c}\text { Expenditures }= \\
\text { Price x Units }\end{array}$ \\
\hline 1 & $5.00 €$ & & 8 & \\
\hline 2 & $2.00 €$ & & 20 & \\
\hline 3 & $1.50 €$ & & 40 & \\
\hline 4 & $1.00 €$ & & 80 & \\
\hline 5 & $0.50 €$ & & & \\
\hline
\end{tabular}




\section{Questionnaire II}

Please fill in questionnaire II.

27. Emission allowances of the European Emissions Trading System (certificates) are traded on the stock exchange. How would you estimate the price of such a permit on the stock exchange?

$100 \mathrm{~kg}$ of $\mathrm{CO}_{2} \operatorname{cost} €$

28. How sure are you about your estimation of question 27 ?

\begin{tabular}{|c|c|c|c|c|}
\hline I know it & Sure & Rather sure & Rather unsure & I don't know, I guessed. \\
\hline & & & & \\
\hline
\end{tabular}

29. Will you talk about this event and your behaviour in it with your family, your friends or your colleagues?
a) Yes
$\mathrm{O}$
b) No
$\mathrm{O}$
c) I don't know
$\mathrm{O}$

Please answer the following questions only if you want to buy permits. That means if you have stated a positive quantity ( $>0)$ at any of the prices in the auction of the permits.

30. I want to buy permits, because...

\begin{tabular}{|l|l|l|l|l|l|}
\hline Reason $\downarrow$ & $\begin{array}{c}\text { Absolutely } \\
\text { not } \\
\text { applicable }\end{array}$ & $\begin{array}{l}\text { Rather not } \\
\text { applicable }\end{array}$ & Neutral & $\begin{array}{c}\text { Rather } \\
\text { applicable }\end{array}$ & $\begin{array}{c}\text { Absolutely } \\
\text { not } \\
\text { applicable }\end{array}$ \\
\hline $\begin{array}{l}\ldots \text {.. want to contribute to climate } \\
\text { protection - regardless of what } \\
\text { others do. }\end{array}$ & & & & & \\
\hline $\begin{array}{l}\ldots \text { I think that others also } \\
\text { contribute to climate protection. }\end{array}$ & & & & & \\
\hline $\begin{array}{l}\ldots \text { especially people in poor } \\
\text { countries will suffer the } \\
\text { consequences of climate change } \\
\text { and I want to do something } \\
\text { against it. }\end{array}$ & & & & \\
\hline $\begin{array}{l}\ldots \text { the industrialised countries, } \\
\text { among them Germany, have } \\
\text { played a decisive role in causing } \\
\text { climate change. }\end{array}$ & & & & & \\
\hline $\begin{array}{l}\ldots \text { future generations will suffer } \\
\text { the consequences of climate } \\
\text { change and I want to do } \\
\text { something against it. }\end{array}$ & & & & & \\
\hline $\begin{array}{l}\ldots \text { the flora and fauna will suffer } \\
\text { the consequences. }\end{array}$ & & & & & \\
\hline $\begin{array}{l}\ldots \text { the government is not doing } \\
\text { enough against climate change. }\end{array}$ & & & & & \\
\hline $\begin{array}{l}\ldots . \text { my environment (family, } \\
\text { friends, colleagues) expects me } \\
\text { to. }\end{array}$ & & & & & \\
\hline $\begin{array}{l}\ldots . \text { the organisers of this event } \\
\text { expect me to. }\end{array}$ & & & & & \\
\hline$\ldots$ it is my moral obligation. & & & & \\
\hline $\begin{array}{l}\ldots \text { it is important to protect the } \\
\text { creation. }\end{array}$ & & & & & \\
\hline
\end{tabular}


31. I do not want to buy permits, because...

\begin{tabular}{|l|l|l|l|l|l|}
\hline Reason $\downarrow$ & $\begin{array}{c}\text { Absolutely } \\
\text { not } \\
\text { applicable }\end{array}$ & $\begin{array}{c}\text { Rather not } \\
\text { applicable }\end{array}$ & Neutral & $\begin{array}{c}\text { Rather } \\
\text { applicable }\end{array}$ & $\begin{array}{c}\text { Absolutely } \\
\text { not } \\
\text { applicable }\end{array}$ \\
\hline $\begin{array}{l}\ldots \text { I do not think that my buying } \\
\text { of permits will actually reduce } \\
\text { emissions in Europe. }\end{array}$ & & & & & \\
\hline $\begin{array}{l}\ldots \text {. market for permits does not } \\
\text { work. We need official } \\
\text { prohibitions and commands. }\end{array}$ & & & & & \\
\hline $\begin{array}{l}\ldots \text { I already act in a climate } \\
\text { conscious way. }\end{array}$ & & & & & \\
\hline $\begin{array}{l}\ldots \text { emissions trading anyhow } \\
\text { suits the interests of the large } \\
\text { scale industry only. }\end{array}$ & & & & & \\
\hline $\begin{array}{l}\ldots \text { I think that emissions trading } \\
\text { is principally unethical. }\end{array}$ & & & & & \\
\hline $\begin{array}{l}\ldots \text { I would buy permits from } \\
\text { companies which have received } \\
\text { them for free and by that subsidy } \\
\text { them. }\end{array}$ & & & & & \\
\hline$\ldots$ I do not trust ZEW. & & & & & \\
\hline $\begin{array}{l}\ldots \text { I do not think that emissions } \\
\text { can actually be measured and } \\
\text { controlled. }\end{array}$ & & & & & \\
\hline
\end{tabular}

More reasons:

Leaving the room

Please leave the room only when we have asked you to.

After leaving the room you will draw a price by lot and pay the certificates you have chosen to buy at this price.

Thank you very much for participating! 